\title{
Enabling Synthesis of ABBV-2222, A CFTR Corrector for the Treatment of Cystic Fibrosis
}

\author{
Stephen N. Greszler*, Bhadra Shelat, Eric A. Voight \\ Centralized Organic Synthesis - Drug Discovery Science and Technology, AbbVie, Inc., 1 N Waukegan Rd, \\ North Chicago, Illinois, 60064
}

General Methods and

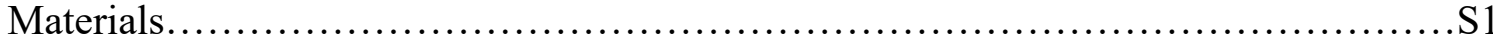

Representative Procedures and Analytical Data for New Compounds.................S2

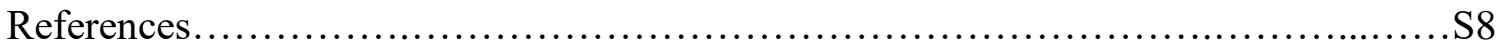

Chiral SFC Analysis of Intermediates............................................... 9

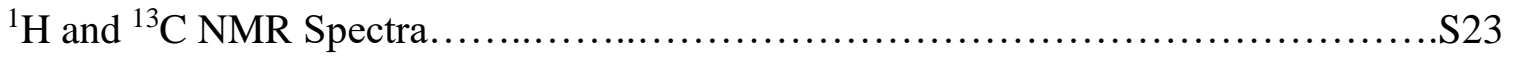

General Materials and Methods

Unless otherwise noted, commercial solvents and reagents were purchased and used without additional purification. Proton and carbon magnetic resonance spectra $\left({ }^{1} \mathrm{H}\right.$ NMR and $\left.{ }^{13} \mathrm{NMR}\right)$ were measured with either a 400 or $500 \mathrm{MHz}$ spectrometer. ${ }^{1} \mathrm{H}$ NMR chemical shifts are expressed in parts per million $(\delta)$ downfield from tetramethylsilane $\left(\mathrm{CHCl}_{3}\right.$ standardized at $\left.7.26 \mathrm{ppm}\right) .{ }^{13} \mathrm{C}$ NMR chemical shifts are expressed in parts per million $(\delta)$ downfield from tetramethylsilane (central peak of $\mathrm{CHCl}_{3}$ standardized at $77.0 \mathrm{ppm}$ ). Spectra were obtained using a Varian $400 \mathrm{MHz}$ or Varian Inova $500 \mathrm{MHz}$ NMR Spectrometer. Reactions were monitored using either LC-MS or thin-layer chromatography (TLC) conditions. Analytical LC-MS was performed on a Thermo MSQ-Plus mass spectrometer and Agilent 1100/1200 HPLC system running Xcalibur 2.0.7, Open-Access 1.4, and custom login software. The mass spectrometer was operated under positive APCI or ESI ionization conditions dependent on the system used.* The HPLC system comprised an Agilent Binary pump, degasser, column compartment, autosampler and diode-array detector, with a Polymer Labs ELS-2100 evaporative light-scattering detector. The column used was a Phenomenex Kinetex $\mathrm{C} 8,2.6 \mu \mathrm{m} 100 \AA(2.1 \mathrm{~mm} \times 30 \mathrm{~mm})$, at a temperature of $65^{\circ} \mathrm{C}$. Visualization of TLC was accomplished with UV light and/or aqueous potassium permanganate or ceric ammonium nitrate stain followed by heating. Purification of the crude reaction products, when performed, was accomplished on a Grace Reveleris X2 normal-phase chromatography system using silica gel cartridges purchased from Grace or Silicycle. Specific parameters used in the separation of individual compounds are detailed under each entry. Unless otherwise noted, reactions were carried out under an atmosphere of nitrogen. Yields refer to isolated yields of analytically pure (>95\%) material unless otherwise noted. 


\section{$\underline{\text { Representative Procedures and Analytical Data for New Compounds }}$}<smiles>COc1ccc2c(=O)ccoc2c1</smiles>

7-methoxy-4H-chromen-4-one

(4):

1-(2-hydroxy-4methoxyphenyl)ethanone $(50.0 \mathrm{~g}, 301 \mathrm{mmol})$ was dissolved in DMF-DMA (50.0 mL, 373 $\mathrm{mmol}$ ), and the solution was heated to $>100{ }^{\circ} \mathrm{C}$ in a sand bath for $10 \mathrm{~min}$. Solids began to form, and the solution turned dark red. After cooling to room temperature, heptanes (200 $\mathrm{mL}$ ) was added and the solids were broken up with a spatula. After slurrying for 15 min at room temperature, the solid was isolated via filtration through a fritted funnel and washed with heptanes $(100 \mathrm{~mL})$. The filter cake was dried in the funnel to give $\sim 60 \mathrm{~g}$ of the crude intermediate, which was dissolved in $750 \mathrm{~mL}$ of DCM and stirred with concentrated $\mathrm{HCl}(100 \mathrm{~mL})$ at $\mathrm{rt}$ for $30 \mathrm{~min}$. The layers were separated and the aqueous layer was extracted with DCM $(2 \times 50 \mathrm{~mL})$. The combined organic extracts were washed with brine $(50 \mathrm{~mL})$, dried over sodium sulfate, and concentrated to give a red solid. The solid was dissolved in 1:1 CPME:heptanes $(500 \mathrm{~mL})$ at $>80^{\circ} \mathrm{C}$, performing an intermediate decantation from insoluble red material. The decantate was cooled to rt, resulting in product crystallization. The solid was isolated via filtration through a fritted funnel and washed with heptanes $(50 \mathrm{~mL})$, then dried to constant weight to give the product $(27 \mathrm{~g})$ as a light pink crystalline solid. The filtrate and undissolved material were recombined and a second crystallization was performed to give additional product $(10.5 \mathrm{~g})$. Combined yield $=37.5 \mathrm{~g}(71 \%) .{ }^{1} \mathrm{H}$ NMR $(400 \mathrm{MHz}$, Chloroform- $d) \delta 8.10(\mathrm{~d}, J=8.9 \mathrm{~Hz}, 1 \mathrm{H}), 7.87-$ $7.71(\mathrm{~m}, 1 \mathrm{H}), 6.96(\mathrm{dd}, J=9.0,2.4 \mathrm{~Hz}, 1 \mathrm{H}), 6.83(\mathrm{~d}, J=2.3 \mathrm{~Hz}, 1 \mathrm{H}), 6.27$ (d, $J=6.0 \mathrm{~Hz}$, $1 \mathrm{H}), 3.89(\mathrm{~s}, 3 \mathrm{H})$. Analytical data matched those reported in the literature ${ }^{1}$ :<smiles>C=CC(=O)C1CC(=O)c2ccc(OC)cc2O1</smiles>

$\mathrm{CO}_{2} \mathrm{Me}$ (R)-methyl 4-(7-methoxy-4-oxochroman-2-yl)benzoate (3): The reported procedure from Stoltz was followed, ${ }^{2}$ except 1,2-DCE was sparged prior to its addition to the flask, water was freeze-pump-thawed prior to its addition, and the reaction was run under $\mathrm{N}_{2}$ in a $250-\mathrm{mL}$ rbf.

1,2-DCE was sparged with a stream of $\mathrm{N}_{2}$ for $1 \mathrm{~h}$. A $500 \mathrm{~mL}$ round-bottomed flask was charged with (S)-4-(tert-butyl)-2-(pyridin-2-yl)-4,5-dihydrooxazole (1.57 g, $7.66 \mathrm{mmol}$ 0.09 equiv), bis(2,2,2-trifluoroacetoxy)palladium( $2.12 \mathrm{~g}, 6.39 \mathrm{mmol}, 0.075$ equiv), (4(methoxycarbonyl)phenyl)boronic acid (30.6 g, $170 \mathrm{mmol}, 2.00$ equiv), and ammonium hexafluorophosphate(V) (4.16 g, $25.5 \mathrm{mmol}, 0.30$ equiv), and sparged 1,2-DCE (85 mL) was added. The resulting suspension was stirred at room temperature for $10 \mathrm{~min}$, at which point 7-methoxy-4H-chromen-4-one ( $15.0 \mathrm{~g}, 85.0 \mathrm{mmol}, 1.00$ equiv) was added, followed by water $(7.70 \mathrm{~mL}, 425 \mathrm{mmol}, 5.0$ equiv) and additional DCE ( $85 \mathrm{~mL})$ was used to rinse the sides of the flask. The flask was heated to an internal temperature of $60{ }^{\circ} \mathrm{C}$ using a 
heating mantle for $16 \mathrm{~h}$ while stirring vigorously. The flask was cooled to room temperature and the resulting dark suspension was filtered through a fritted funnel containing a 1-inch pad of silica while eluting with $\mathrm{CH}_{2} \mathrm{Cl}_{2}$ to remove solid material and unreacted boronic acid. The filtrates were concentrated in vacuo to give a light yellow solid, which was recrystallized from 1:1 MTBE:heptanes $(200 \mathrm{~mL})$ to give the title compound (13.1 g, 45\% yield adjusted for the solid purity) as an off-white solid that was contaminated with $\sim 9 \%$ of the biphenyl byproduct dimethyl [1,1'-biphenyl]-4,4'dicarboxylate, which was more easily rejected downstream and carried through to the subsequent oxime formation. Analytical data: ${ }^{1} \mathrm{H}$ NMR $\left(500 \mathrm{MHz}, \mathrm{CDCl}_{3}\right) \delta 8.10(\mathrm{~d}, J=$ $8.3 \mathrm{~Hz}, 2 \mathrm{H}), 7.87(\mathrm{~d}, J=8.9 \mathrm{~Hz}, 1 \mathrm{H}), 7.55(\mathrm{~d}, J=8.4 \mathrm{~Hz}, 2 \mathrm{H}), 6.63(\mathrm{dd}, J=8.9,2.4 \mathrm{~Hz}$, $1 \mathrm{H}), 6.52(\mathrm{~d}, J=2.4 \mathrm{~Hz}, 1 \mathrm{H}), 5.53(\mathrm{dd}, J=13.0,3.2 \mathrm{~Hz}, 1 \mathrm{H}), 3.93(\mathrm{~s}, 3 \mathrm{H}), 3.85(\mathrm{~s}, 3 \mathrm{H})$, $2.98(\mathrm{dd}, J=16.8,13.0 \mathrm{~Hz}, 1 \mathrm{H}), 2.85(\mathrm{dd}, J=16.9,3.1 \mathrm{~Hz}, 1 \mathrm{H}) ;{ }^{13} \mathrm{C} \mathrm{NMR}(101 \mathrm{MHz}$, $\left.\mathrm{CDCl}_{3}\right) \delta 189.8,166.6,166.3,163.2,143.7,130.4,130.1,128.8,125.9,114.8,110.4,101.0$, 79.3, 55.7, 52.2, 44.3; ESI-HRMS: Calculated for $\mathrm{C}_{18} \mathrm{H}_{17} \mathrm{O}_{5}[\mathrm{M}+\mathrm{H}]^{+}$: 313.1071; found: 313.1075. Specific rotation: $[\boldsymbol{\alpha}]_{\mathrm{D}}{ }^{23}=\mathbf{+ 9 8 . 4}\left(c=1.00, \mathrm{CH}_{2} \mathrm{Cl}_{2}\right)$

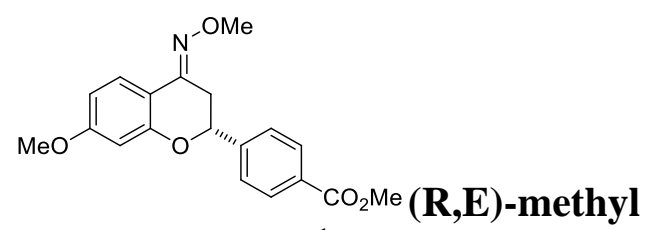

4-(7-methoxy-4-(methoxyimino)chroman-2yl)benzoate (5a): ${ }^{1} \mathrm{H}$ NMR $\left(500 \mathrm{MHz}\right.$, DMSO- $\left.d_{6}\right) \delta 8.11-8.04(\mathrm{~m}, 1 \mathrm{H}), 8.00(\mathrm{~d}, J=8.3$ $\mathrm{Hz}, 2 \mathrm{H}), 7.70(\mathrm{~d}, J=8.8 \mathrm{~Hz}, 1 \mathrm{H}), 7.65(\mathrm{~d}, J=8.3 \mathrm{~Hz}, 2 \mathrm{H}), 6.64-6.52(\mathrm{~m}, 2 \mathrm{H}), 5.31(\mathrm{dd}$, $J=11.8,3.3 \mathrm{~Hz}, 1 \mathrm{H}), 3.87(\mathrm{~s}, 3 \mathrm{H}), 3.86(\mathrm{~s}, 3 \mathrm{H}), 3.75(\mathrm{~s}, 3 \mathrm{H}), 2.70(\mathrm{dd}, J=17.1,11.9 \mathrm{~Hz}$, 1H); ESI-LCMS: Calculated for $\mathrm{C}_{19} \mathrm{H}_{20} \mathrm{NO}_{5}[\mathrm{M}+\mathrm{H}]^{+}$: 342.1; found: 341.9 .

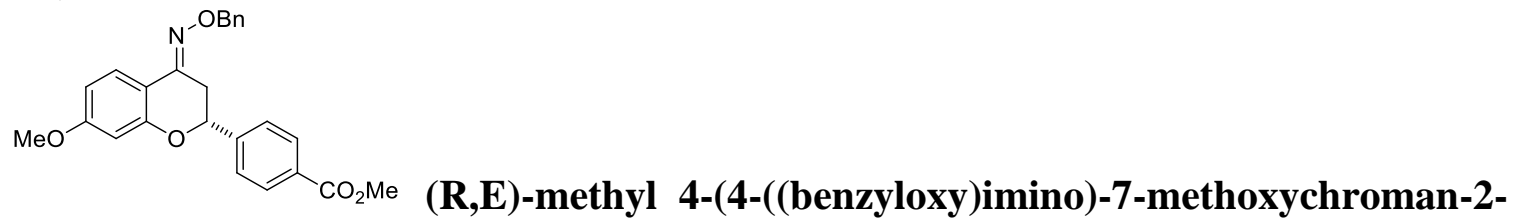

yl)benzoate (5b): -(7-methoxy-4-oxochroman-2-yl)benzoate $(29.5 \mathrm{~g}, 95.0 \mathrm{mmol}, 1.0$ equiv) was dissolved in dry pyridine $(200 \mathrm{~mL})$. O-Benzylhydroxylamine hydrochloride (15.8 $\mathrm{g}, 99.0 \mathrm{mmol}, 1.05$ equiv) was added, and the flask was heated to an internal temperature of $70{ }^{\circ} \mathrm{C}$ for $3 \mathrm{~h}$. The flask was cooled to room temperature, and insoluble material was removed via filtration through a fritted funnel (insoluble material was primarily the biaryl byproduct from the previous step) and washed with pyridine $(10 \mathrm{~mL})$. The filtrate was concentrated in vacuo and partitioned between MTBE $(300 \mathrm{~mL})$ and saturated aqueous ammonium chloride $(150 \mathrm{~mL})$. The organic extracts were washed with brine and dried over sodium sulfate then concentrated in vacuo and triturated with heptanes $(300 \mathrm{~mL})$ to give the title compound ( $39.05 \mathrm{~g}, 94 \%$ yield) as a white solid that was used without additional purification. The product was a mixture of oxime diastereomers. Analytical data for major isomer: ${ }^{1} \mathrm{H}$ NMR $\left(400 \mathrm{MHz}, \mathrm{CDCl}_{3}\right) \delta 8.06(\mathrm{~d}, J=8.4 \mathrm{~Hz}, 2 \mathrm{H})$, $7.84(\mathrm{~d}, J=8.8 \mathrm{~Hz}, 1 \mathrm{H}), 7.52(\mathrm{~d}, J=8.4 \mathrm{~Hz}, 2 \mathrm{H}), 7.42-7.27(\mathrm{~m}, 5 \mathrm{H}), 6.58(\mathrm{dd}, J=8.8$, $2.6 \mathrm{~Hz}, 1 \mathrm{H}), 6.49(\mathrm{~d}, J=2.5 \mathrm{~Hz}, 1 \mathrm{H}), 5.20(\mathrm{dd}, J=11.0,1.8 \mathrm{~Hz}, 2 \mathrm{H}), 5.12(\mathrm{dd}, J=12.2$, $3.2 \mathrm{~Hz}, 1 \mathrm{H}), 3.92(\mathrm{~s}, 3 \mathrm{H}), 3.79$ (s, 3H), $3.48(\mathrm{dd}, J=17.3,3.2 \mathrm{~Hz}, 1 \mathrm{H}), 2.68(\mathrm{dd}, J=17.2$, $12.3 \mathrm{~Hz}, 1 \mathrm{H}) ;$; ESI-LCMS: Calculated for $\mathrm{C}_{25} \mathrm{H}_{24} \mathrm{NO}_{5}[\mathrm{M}+\mathrm{H}]^{+}$: 418.2; found: 418.2. 


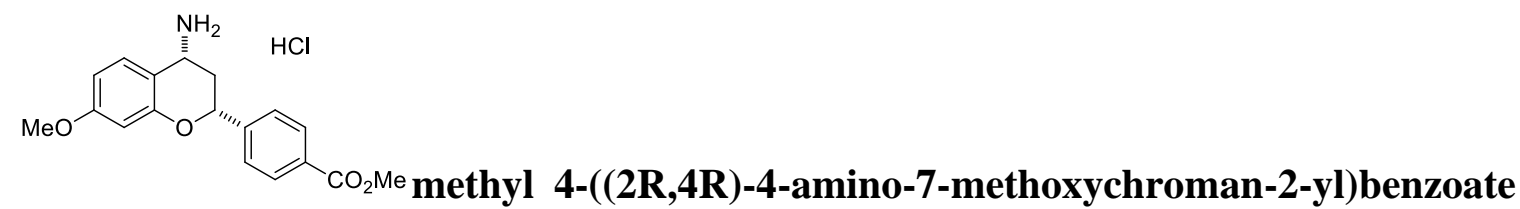

hydrochloride (2): (R,E)-methyl 4-(4-((benzyloxy)imino)-7-methoxychroman-2yl)benzoate (47.5 g, $114 \mathrm{mmol}, 1.0$ equiv) and HOAc $(715 \mathrm{~mL})$ were added to $5 \% \mathrm{Pt} / \mathrm{C}$ wet, RD0585 (0.45 g, $0.948 \mathrm{mmol})(7.5 \%$ of $5 \% \mathrm{Pt} / \mathrm{C}$ wet) in a $250 \mathrm{~mL}$ stainless steel pressure bottle and stirred for $16 \mathrm{~h}$ at $30 \mathrm{psi}$ and room temperature for $30 \mathrm{~h}$, at which point HPLC analysis indicated $\sim 85 \%$ conversion. Additional $5 \% \mathrm{Pt} / \mathrm{C}$ wet, RD0585 (0.15 g, $0.316 \mathrm{mmol})(2.5 \%$ of $5 \% \mathrm{Pt} / \mathrm{C}$ wet or $1.03 \% 5 \% \mathrm{Pt} / \mathrm{C}$ dry) catalyst was added, and the hydrogenation was continued for a further $2 \mathrm{~h}$, at which point $<3 \%$ residual starting material was present by HPLC. The solid material was removed via filtration through a 0.45 micron paper, and the filtrate was concentrated in vacuo at $50{ }^{\circ} \mathrm{C}$ bath temperature to give crude material (69 g, approximately $200 \mathrm{wt} \%$ of theoretical mass). The resulting thick oil was suspended in MTBE $(275 \mathrm{~mL})$ and heptanes $(40 \mathrm{~mL})$. The mixture was heated to $70{ }^{\circ} \mathrm{C}$ using a heating mantle, and glacial acetic acid $(70 \mathrm{~mL})$ was added in $10 \mathrm{~mL}$ portions until a clear solution was observed. Hydrochloric acid (3M in CPME, $69.0 \mathrm{~mL}, 2.0$ equiv) was added dropwise via syringe over $5 \mathrm{~min}$, and the title compound began to crystallize from the reaction mixture near the endpoint of addition. The flask was allowed to cool to room temperature over $1 \mathrm{~h}$, at which point the resulting yellow solid was isolated via filtration through a $600 \mathrm{~mL}$ fritted funnel and washed with cold MTBE $(2 \times 80 \mathrm{~mL})$. The solid was then suspended in toluene $(320 \mathrm{~mL})$ and heated to $70{ }^{\circ} \mathrm{C}$, then cooled to room temperature and isolated via filtration through a fritted funnel. The solid was washed with toluene (40 $\mathrm{mL})$ and heptanes $(40 \mathrm{~mL})$ and then dried in a vacuum oven at $50{ }^{\circ} \mathrm{C}$ for $16 \mathrm{~h}$, giving the title compound (28.2 g, 78\% yield) as a white solid. ${ }^{1} \mathrm{H}$ NMR showed a $50: 1$ diastereomeric ratio for the isolated hydrochloride salt and chiral SFC analysis showed $>98 \%$ ee. Analytical data: ${ }^{1} \mathrm{H}$ NMR (400 MHz, DMSO- $\left.d 6\right) \delta 8.90(\mathrm{~s}, 3 \mathrm{H}), 8.02$ (d, $J=7.9$ $\mathrm{Hz}, 2 \mathrm{H}), 7.62(\mathrm{dd}, J=20.4,8.3 \mathrm{~Hz}, 3 \mathrm{H}), 6.63(\mathrm{dd}, J=8.7,2.6 \mathrm{~Hz}, 1 \mathrm{H}), 6.51(\mathrm{~d}, J=2.6$ $\mathrm{Hz}, 1 \mathrm{H}), 5.35(\mathrm{~d}, J=11.6 \mathrm{~Hz}, 1 \mathrm{H}), 4.74(\mathrm{~d}, J=9.0 \mathrm{~Hz}, 1 \mathrm{H}), 3.85(\mathrm{~s}, 3 \mathrm{H}), 3.72(\mathrm{~s}, 3 \mathrm{H}), 2.59$ $(\mathrm{dd}, J=13.1,6.2 \mathrm{~Hz}, 1 \mathrm{H}), 1.99$ (q, $J=12.1 \mathrm{~Hz}, 1 \mathrm{H}) ;{ }^{13} \mathrm{C}$ NMR $(101 \mathrm{MHz}, \mathrm{DMSO}-d 6) \delta$ 166.53, 160.78, 156.04, 145.36, 129.96, 129.90, 128.34, 126.80, 112.08, 108.75, 102.03, 75.75, 55.75, 52.69, 45.46, 34.96; ESI-HRMS: Calculated for $\mathrm{C}_{18} \mathrm{H}_{20} \mathrm{NO}_{4}[\mathrm{M}+\mathrm{Na}]^{+}$: 336.1206; found: 336.1210; Specific rotation: $[\boldsymbol{\alpha}]_{\mathrm{D}}{ }^{22.6}=+\mathbf{3 6 . 2}(c=1.00, \mathrm{MeOH})$

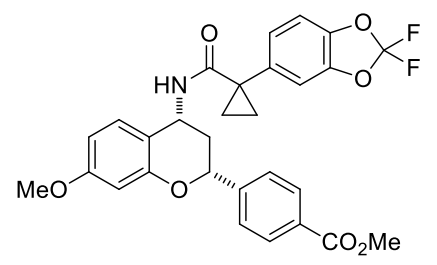

methyl 4-((2R,4R)-4-(1-(2,2-difluorobenzo[d][1,3]dioxol-5yl)cyclopropanecarboxamido)-7-methoxychroman-2-yl)benzoate $\quad$ (7): $\quad$ 1-(2,2difluorobenzo[d][1,3]dioxol-5-yl)cyclopropanecarboxylic acid (104 g, $429 \mathrm{mmol}, 1.0$ equiv) was dissolved in dichloromethane $(1.07 \mathrm{~L})$ and oxalyl chloride $(83 \mathrm{~mL}, 945 \mathrm{mmol}$, 2.2 equiv) was added, followed by $\mathrm{DMF}(0.333 \mathrm{~mL}, 4.29 \mathrm{mmol}, 0.01$ equiv). After stirring 
at room temperature for $4 \mathrm{~h}$, the volatiles were removed in vacuo. The residue was redissolved in DCM $(15 \mathrm{~mL})$ and concentrated. The resulting oil was dissolved in dichloromethane $(200 \mathrm{~mL})$ and used immediately in the coupling reaction:

methyl 4-((2R,4R)-4-amino-7-methoxychroman-2-yl)benzoate hydrochloride (150 g, 429 mmol, 1.0 equiv) was suspended in dichloromethane $(1.47 \mathrm{~L})$ in a $3 \mathrm{~L} 3$-neck roundbottomed flask with attached overhead stirring apparatus. The resulting suspension was cooled to $<5{ }^{\circ} \mathrm{C}$ in an ice-water bath. Triethylamine (179 ml, $1.29 \mathrm{M} .3 .0$ equiv) was added over $5 \mathrm{~min}$ via syringe (a slight exotherm to $\sim 15{ }^{\circ} \mathrm{C}$ was noted), and once the temperature had again returned to $<5^{\circ} \mathrm{C}$, a solution of the acid chloride in dichloromethane $(200 \mathrm{~mL})$ was added dropwise via addition funnel over $15 \mathrm{~min}$, maintaining an internal temperature below $15{ }^{\circ} \mathrm{C}$. After the addition was complete, the reaction was stirred at the same temperature for $15 \mathrm{~min}$, at which point complete conversion to the desired product had occurred. The reaction was quenched by the addition of $1 \mathrm{M} \mathrm{HCl}(750 \mathrm{~mL})$ and the resulting biphasic mixture was stirred for $10 \mathrm{~min}$ at room temperature. The layers were separated, and the organic layer was washed with $1 \mathrm{M} \mathrm{HCl}(3 \times 500 \mathrm{~mL})$ and brine $(250$ $\mathrm{mL}$ ). After drying over sodium sulfate and concentrating in vacuo, a crude solid was obtained $(240 \mathrm{~g})$. The crude solid was dissolved in ethyl acetate $(400 \mathrm{~mL})$ and the solution was heated to $75^{\circ} \mathrm{C}$ with a heating mantle. Heptanes $(1.2 \mathrm{~L})$ was added slowly via addition funnel while stirring with an overhead stirring apparatus. The flask was cooled to room temperature over 90 min while stirring and was then cooled to $<5{ }^{\circ} \mathrm{C}$ for an additional 30 min. The resulting white solid was isolated via filtration using a fritted funnel and was washed with cold 5:95 ethyl acetate:heptanes $(500 \mathrm{~mL})$ and heptanes $(500 \mathrm{~mL})$ then dried to constant weight in a vacuum oven at $50{ }^{\circ} \mathrm{C}$ to give the title compound $(200.1 \mathrm{~g}, 87 \%$ yield) as a white solid with an HPLC purity of $>99 \%(205 \mathrm{~nm})$. Chiral SFC showed a single enantiomer.

Analytical data: ${ }^{1} \mathrm{H}$ NMR $\left(400 \mathrm{MHz}, \mathrm{CDCl}_{3}\right) \delta 8.08-7.99(\mathrm{~m}, 2 \mathrm{H}), 7.45(\mathrm{~d}, J=8.3 \mathrm{~Hz}$, $2 \mathrm{H}), 7.12-7.03(\mathrm{~m}, 2 \mathrm{H}), 7.03-6.90(\mathrm{~m}, 2 \mathrm{H}), 6.51(\mathrm{dd}, J=8.6,2.6 \mathrm{~Hz}, 1 \mathrm{H}), 6.44(\mathrm{~d}, J=$ $2.5 \mathrm{~Hz}, 1 \mathrm{H}), 5.40$ (dddd, $J=10.5,8.8,6.0,1.0 \mathrm{~Hz}, 1 \mathrm{H}), 5.31(\mathrm{~d}, J=8.7 \mathrm{~Hz}, 1 \mathrm{H}), 5.22$ (dd, $J=11.1,2.0 \mathrm{~Hz}, 1 \mathrm{H}), 3.93(\mathrm{~s}, 3 \mathrm{H}), 3.75(\mathrm{~s}, 3 \mathrm{H}), 2.50(\mathrm{ddd}, J=13.3,6.0,2.1 \mathrm{~Hz}, 1 \mathrm{H}), 1.81$ - 1.69 (m, 2H), $1.69-1.55$ (m, 2H), $1.14-0.96(\mathrm{~m}, 2 \mathrm{H}) ;{ }^{13} \mathrm{C} \mathrm{NMR}\left(101 \mathrm{MHz}, \mathrm{CDCl}_{3}\right) \delta$ 173.2, 166.7, 160.4, 155.8, 145.4, 144.0, 143.4, 133.7 (t, $J=193 \mathrm{~Hz}, \mathrm{CF}_{2}$ ), 129.9, 129.9, 129.6, 127.4, 126.3, 125.7, 114.7, 112.0, 109.9, 108.6, 101.7, 55.4, 52.1, 45.2, 37.3, 30.4, 16.4, 16.2; ${ }^{19} \mathrm{~F}$ NMR (376 MHz, $\left.\mathrm{CDCl}_{3}\right) \delta$-49.8; ESI-HRMS: Calculated for $\mathrm{C}_{29} \mathrm{H}_{26} \mathrm{~F}_{2} \mathrm{NO}_{7}$ $[\mathrm{M}+\mathrm{H}]^{+}:$538.1672; found: 538.1680. Specific rotation: $[\boldsymbol{\alpha}]_{\mathrm{D}}{ }^{22.7}=+\mathbf{1 4 . 8}(c=1.00, \mathrm{MeOH})$

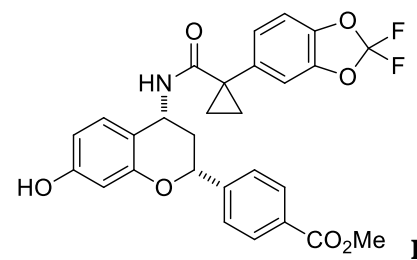

methyl 4-((2R,4R)-4-(1-(2,2-difluorobenzo[d][1,3]dioxol-5yl)cyclopropanecarboxamido)-7-hydroxychroman-2-yl)benzoate (8): A solution of methyl 4-((2R,4R)-4-(1-(2,2-difluorobenzo[d][1,3]dioxol-5yl)cyclopropanecarboxamido)-7-methoxychroman-2-yl)benzoate (170 g, $316 \mathrm{mmol}, 1.0$ equiv) and tetrabutylammonium iodide $(350 \mathrm{~g}, 949 \mathrm{mmol})$ in dichloromethane $(1.7 \mathrm{~L})$ was 
cooled to $<-20^{\circ} \mathrm{C}$ and boron trichloride (1M in dichloromethane, $0.949 \mathrm{~L}, 949 \mathrm{mmol}$ ) was added over $15 \mathrm{~min}$ via addition funnel, maintaining the internal temperature between -25 and $-20{ }^{\circ} \mathrm{C}$. The reaction temperature was held constant in the same range for an additional $1 \mathrm{~h}$, at which point HPLC analysis showed $<0.5 \%$ starting material remaining, and the reaction mixture was poured into water $(850 \mathrm{~mL})$ at $<5{ }^{\circ} \mathrm{C} . \mathrm{CH}_{2} \mathrm{Cl}_{2}$ was reduced to approximately $350 \mathrm{~mL}$ in vacuo, and MTBE $(850 \mathrm{~mL})$ was added. The organic layer was reduced in vacuo to minimal volume and of MTBE $(1.7 \mathrm{~L})$ was added. The resulting slurry was stirred for $30 \mathrm{~min}$ and solid material was removed via filtration through a fritted funnel, washing with MTBE $(2 \times 340 \mathrm{~mL})$. The filtrate layers were separated, and the organic layer was washed with water $(340 \mathrm{~mL})$, brine $(170 \mathrm{~mL})$, and filtered through $510 \mathrm{~g}$ (300 wt\%) silica gel, washing the silica plug with MTBE $(2 \times 510 \mathrm{~mL})$. The filtrate was concentrated in vacuo and dried overnight under house vacuum to give the title compound (166 g, $317 \mathrm{mmol}, 100 \mathrm{wt} \%$ theoretical yield) as a white foam that was used without additional purification. HPLC purity was $93.1 \%$ at $220 \mathrm{~nm}$, with 5.4 PA\% ester demethylation observed. Analytical data: ${ }^{1} \mathrm{H}$ NMR $\left(400 \mathrm{MHz}, \mathrm{CDCl}_{3}\right) \delta 8.00(\mathrm{~d}, J=8.4$ $\mathrm{Hz}, 2 \mathrm{H}), 7.40(\mathrm{~d}, J=8.3 \mathrm{~Hz}, 2 \mathrm{H}), 7.14-7.04(\mathrm{~m}, 2 \mathrm{H}), 6.99(\mathrm{~d}, J=8.1 \mathrm{~Hz}, 1 \mathrm{H}), 6.88(\mathrm{~d}, J$ $=8.4 \mathrm{~Hz}, 1 \mathrm{H}), 6.45(\mathrm{dd}, J=8.4,2.5 \mathrm{~Hz}, 1 \mathrm{H}), 6.41(\mathrm{~s}, 1 \mathrm{H}), 6.31-6.16(\mathrm{~m}, 1 \mathrm{H}), 5.36(\mathrm{q}, J$ $=4.5 \mathrm{~Hz}, 2 \mathrm{H}), 5.15(\mathrm{dd}, J=11.1,1.9 \mathrm{~Hz}, 1 \mathrm{H}), 3.92(\mathrm{~s}, 3 \mathrm{H}), 2.47(\mathrm{ddd}, J=11.4,4.8,2.1$ $\mathrm{Hz}, 1 \mathrm{H}), 1.84-1.66(\mathrm{~m}, 3 \mathrm{H}), 1.66-1.58(\mathrm{~m}, 1 \mathrm{H}), 1.12-1.02(\mathrm{~m}, 2 \mathrm{H})$; ESI-LCMS: Calculated for $\mathrm{C}_{28} \mathrm{H}_{22} \mathrm{~F}_{2} \mathrm{NO}_{7}[\mathrm{M}-\mathrm{H}]$ ]: 522.1; found: 522.1 .

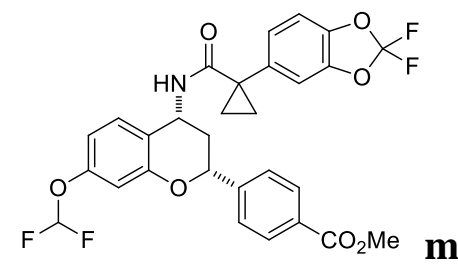

yl)cyclopropanecarboxamido)-7-(difluoromethoxy)chroman-2-yl)benzoate

(9):

Analytical data: ${ }^{1} \mathrm{H}$ NMR $\left(400 \mathrm{MHz}, \mathrm{CDCl}_{3}\right) \delta^{1} \mathrm{H}$ NMR (400 MHz, Chloroform- $d$ ) $\delta 8.05$ $(\mathrm{d}, J=8.3 \mathrm{~Hz}, 2 \mathrm{H}), 7.45(\mathrm{~d}, J=8.4 \mathrm{~Hz}, 2 \mathrm{H}), 7.17-6.94(\mathrm{~m}, 4 \mathrm{H}), 6.77-6.59(\mathrm{~m}, 2 \mathrm{H})$, $6.47(\mathrm{t}, J=72 \mathrm{~Hz}, 1 \mathrm{H}), 5.52-5.38(\mathrm{~m}, 1 \mathrm{H}), 5.33(\mathrm{~d}, J=8.9 \mathrm{~Hz}, 1 \mathrm{H}), 5.25(\mathrm{dd}, J=11.2$, $1.9 \mathrm{~Hz}, 1 \mathrm{H}), 3.93(\mathrm{~s}, 3 \mathrm{H}), 2.50$ (ddd, $J=13.4,6.0,2.1 \mathrm{~Hz}, 1 \mathrm{H}), 1.84-1.60(\mathrm{~m}, 3 \mathrm{H}), 1.14$ - $1.03(\mathrm{~m}, 2 \mathrm{H}) ;{ }^{19} \mathrm{~F}$ NMR $\left(376 \mathrm{MHz}, \mathrm{CDCl}_{3}\right) \delta-49.8,-81.2(\mathrm{~d}, J=75 \mathrm{~Hz})$; ESI-LCMS: Calculated for $\mathrm{C}_{29} \mathrm{H}_{24} \mathrm{~F}_{4} \mathrm{NO}_{7}[\mathrm{M}+\mathrm{H}]^{+}$: 574.1; found: 574.0.

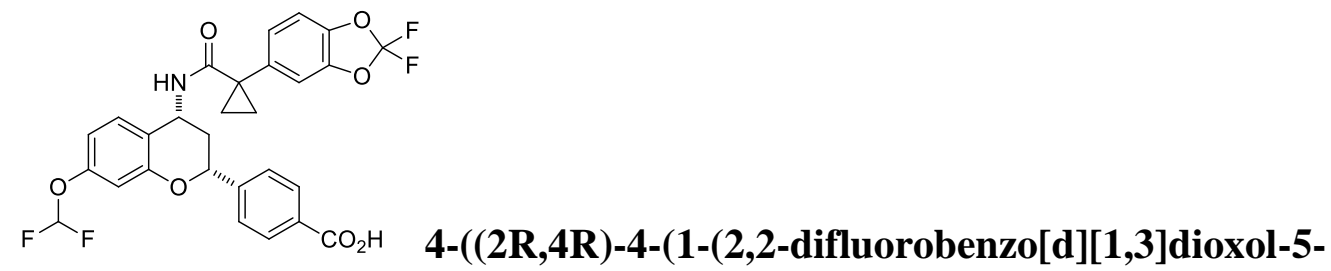
yl)cyclopropanecarboxamido)-7-(difluoromethoxy)chroman-2-yl)benzoic acid (ABBV-2222): A solution of methyl 4-((2R,4R)-4-(1-(2,2-difluorobenzo[d][1,3]dioxol-5yl)cyclopropanecarboxamido)-7-hydroxychroman-2-yl)benzoate (165 g, $316 \mathrm{mmol}, 1.0$ equiv) in acetonitrile $(1.65 \mathrm{~L})$ was cooled to $<-20{ }^{\circ} \mathrm{C}$ and aqueous potassium hydroxide (1.58 L, $6.32 \mathrm{M}, 20$ equiv) was added between -25 and $-18{ }^{\circ} \mathrm{C}$ over 15 min via addition funnel. Diethyl (bromodifluoromethyl)phosphonate ( $84 \mathrm{~mL}, 474 \mathrm{mmol}, 1.5$ equiv) was 
added between -25 and $-20{ }^{\circ} \mathrm{C}$, and the reaction was held at the same temperature for 15 min. The flask was warmed to $20^{\circ} \mathrm{C}$ over $25 \mathrm{~min}$ then $\mathrm{MeOH}(825 \mathrm{~mL})$ was added. The reaction mixture was warmed to $40{ }^{\circ} \mathrm{C}$ for $10 \mathrm{~min}$, then the mixture was recooled to $15{ }^{\circ} \mathrm{C}$, poured into IPAc $(1.65 \mathrm{~L})$ and the layers were separated. $\mathrm{HCl}(1 \mathrm{M}, 474 \mathrm{~mL}, 948 \mathrm{mmol}, 3$ equiv) was added to the organic layer, and the mixture was heated to $40{ }^{\circ} \mathrm{C}$ for $10 \mathrm{~min}$ to completely convert the aryl formate byproduct to the phenoxy acid. The flask was cooled to room temperature, the layers were separated, and the organic layer was washed with brine $(500 \mathrm{~mL}), 2 \mathrm{M} \mathrm{KOH}(800 \mathrm{~mL}$; $\mathrm{pH} \sim 13)$, and $1 \mathrm{M} \mathrm{KOH}(800 \mathrm{~mL} \times 3)$, to remove the hydroxyacid byproduct. The organic layer was washed with $1 \mathrm{M} \mathrm{HCl}(237 \mathrm{~mL}, 474 \mathrm{mmol})$ to give $\mathrm{pH} 1$ and brine $(330 \mathrm{~mL})$ then dried over sodium sulfate and concentrated at $50{ }^{\circ} \mathrm{C}$ bath temperature to give crude product $(170 \mathrm{~g})$. The resulting foam was dissolved in $\mathrm{MeOH}(528 \mathrm{~mL})$ and heated to $50-55^{\circ} \mathrm{C}$, then water $(132 \mathrm{~mL})$ was added between 50 and $55{ }^{\circ} \mathrm{C}$ to give a hazy solution that was seeded with $0.1 \mathrm{wt} \%$ of previously prepared desired product. The internal temperature was held at $50-55^{\circ} \mathrm{C}$ for $10 \mathrm{~min}$ to give a thick slurry, which was then cooled to $0{ }^{\circ} \mathrm{C}$ over $30 \mathrm{~min}$ and filtered, washing the isolated solid with ice-cold $20 \%$ aq $\mathrm{MeOH}(165 \mathrm{~mL})$. The obtained white solid was dried in a vacuum oven at $50{ }^{\circ} \mathrm{C}$ to constant weight to give the title compound (135 g, 76\% yield over 3 steps) as a white solid with $99.3 \%$ potency as determined by HPLC analysis. Analytical data: ${ }^{1} \mathrm{H}$ NMR (400 MHz, $\left.\left.\mathrm{CDCl}_{3}\right) \delta ;{ }^{13} \mathrm{C} \mathrm{NMR} \mathrm{(101} \mathrm{MHz,} \mathrm{CDCl}_{3}\right) \delta 8.11(\mathrm{~d}, J=8.3 \mathrm{~Hz}, 2 \mathrm{H}), 7.49$ $(\mathrm{d}, J=8.3 \mathrm{~Hz}, 2 \mathrm{H}), 7.17-6.93(\mathrm{~m}, 4 \mathrm{H}), 6.74-6.65(\mathrm{~m}, 2 \mathrm{H}), 6.47(\mathrm{t}, J=73.7 \mathrm{~Hz}, 1 \mathrm{H})$, $5.48(\mathrm{td}, J=10.5,10.1,6.1 \mathrm{~Hz}, 1 \mathrm{H}), 5.38(\mathrm{~d}, J=8.9 \mathrm{~Hz}, 1 \mathrm{H}), 5.27(\mathrm{dd}, J=11.4,1.9 \mathrm{~Hz}$, $1 \mathrm{H}), 2.53$ (ddd, $J=13.4,6.0,2.1 \mathrm{~Hz}, 1 \mathrm{H}), 1.83-1.62(\mathrm{~m}, 3 \mathrm{H}), 1.19-0.99(\mathrm{~m}, 2 \mathrm{H}) ;{ }^{13} \mathrm{C}$ NMR (101 MHz, $\left.\mathrm{CDCl}_{3}\right) \delta^{13} \mathrm{C}$ NMR $(126 \mathrm{MHz}$, Chloroform- $d$ ) $\delta 173.62,170.72,155.78$, 151.57, 151.54, 151.52, 145.72, 144.06, 143.46, 135.30, 131.63 (t, $\left.J=205 \mathrm{~Hz},(\mathrm{ArO})_{2} \mathrm{CF}_{2}\right)$, $129.59,129.29,127.70,126.29,125.77,119.82,115.66$ (t, $\left.J=209 \mathrm{~Hz}, \mathrm{ArO}-\mathrm{CHF}_{2}\right), 112.57$, 112.02, 110.02, 108.18, 45.24, 36.98, 30.41, 16.59, 16.45; ${ }^{19} \mathrm{~F} \mathrm{NMR}\left(376 \mathrm{MHz}, \mathrm{CDCl}_{3}\right) \delta$ $-49.8,-81.2(\mathrm{~d}, J=75 \mathrm{~Hz})$; ESI-HRMS: Calculated for $[\mathrm{M}+\mathrm{H}]^{+}$: 560.1327 ; found: 560.1333. Optical rotation: $[\boldsymbol{\alpha}]_{\mathrm{D}}{ }^{22.9}=+\mathbf{3 0 . 8}(c=1.00, \mathrm{MeOH})$

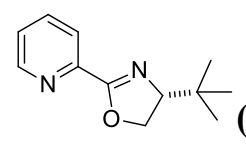

(R)-4-(tert-butyl)-2-(pyridin-2-yl)-4,5-dihydrooxazole (S1): Prepared following the literature procedure ${ }^{2}$ but using (R)-2-amino-3,3-dimethylbutan-1-ol. Spectral data matched those reported in the literature with the expected antipode for optical rotation: $[\boldsymbol{\alpha}]_{\mathrm{D}}{ }^{23.1}=+\mathbf{6 4 . 8}(c=1.00, \mathrm{MeOH})$.

*All other antipodes characterized below were prepared using the procedures given for intermediates leading to ABBV-2222.

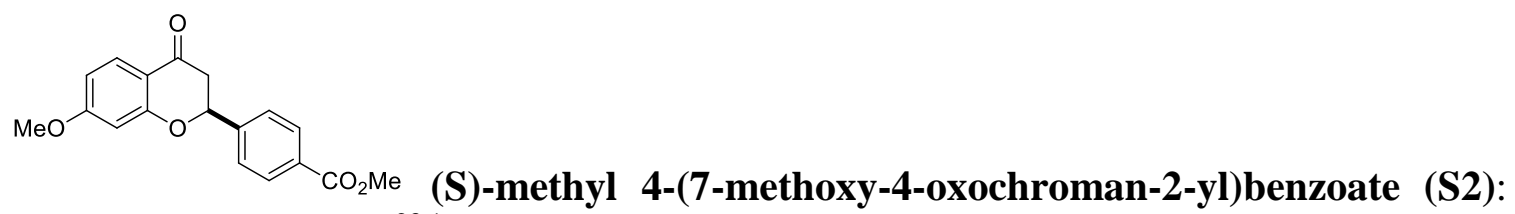

Optical rotation: $[\boldsymbol{\alpha}]_{\mathrm{D}}{ }^{23.1}=\mathbf{- 1 0 8 . 2}\left(c=1.00, \mathrm{CH}_{2} \mathrm{Cl}_{2}\right)$. Other spectral data matched its antipode 3. 


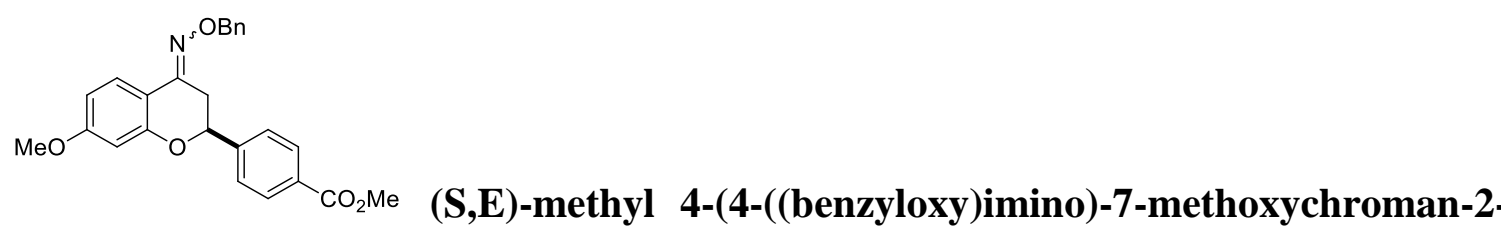

yl)benzoate (S3): spectral data matched the antipode 5b. Optical rotation data not taken due to the mixture of isomers present.

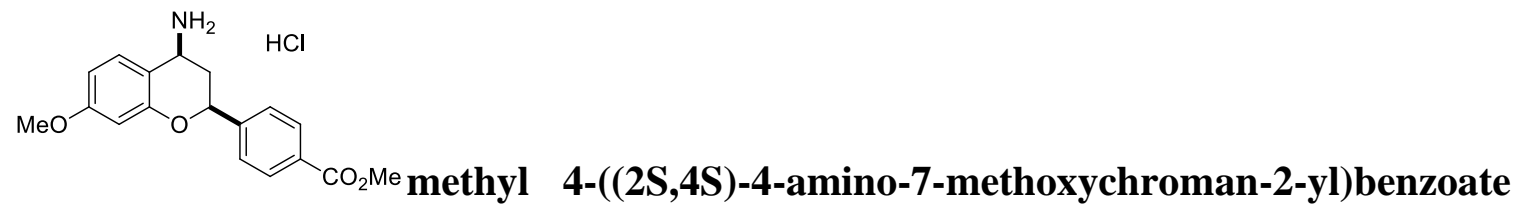

hydrochloride (S4): Optical rotation: $[\boldsymbol{\alpha}]_{\mathrm{D}}{ }^{22.7}=-37.0(c=1.00, \mathrm{MeOH})$. Other spectral data matched its antipode 2.

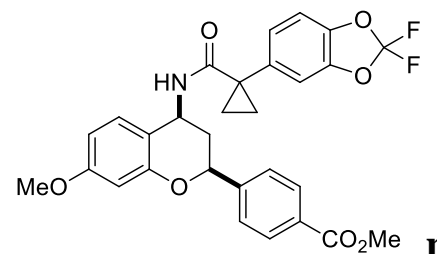

methyl 4-((2R,4R)-4-(1-(2,2-difluorobenzo[d][1,3]dioxol-5yl)cyclopropanecarboxamido)-7-methoxychroman-2-yl)benzoate (S5):

Optical rotation: $[\boldsymbol{\alpha}]_{\mathrm{D}}{ }^{22.8}=\mathbf{- \mathbf { 1 3 . 1 }}(c=1.00, \mathrm{MeOH})$. Other spectral data matched its antipode 7.

References:

1. Chand, K.; Tiwari, R. K.; Kumar, S.; Shirazi, A. N.; Sharma, S.; Van der Eycken, E. V.; Parmar, V. S.; Parang, P. K.; Sharmaa, S. K.; J. Heterocyclic Chem., 2015, $52,562$.

2. Holder, J. C.; Marziale, A. N.; Gatti, M.; Mao, B.; Stoltz, B. M. Chem. Eur J., 2013, $19,74$. 
Chiral SFC Analysis of Intermediates:

I. Stoltz-Hayashi Addition

Enantiomeric Mixture (3 mixed with S2):

\section{APS Group SFC Report}

\section{abbvie}
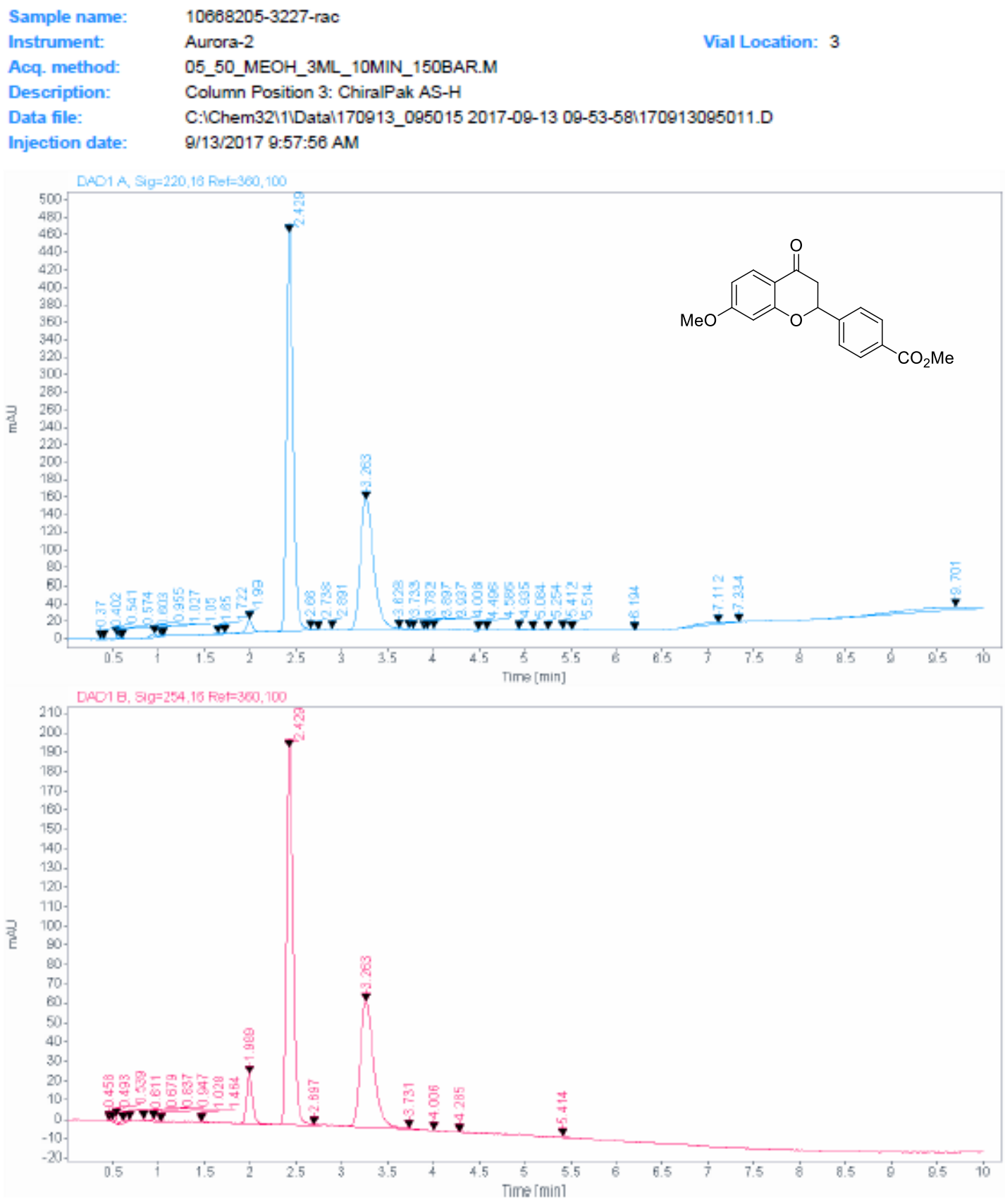


\section{APS Group SFC Report}

Signal: $\quad$ DAD1 A, Sig=220,16 Ref $=360,100$

RT [min] Type Width [min]

$\begin{array}{lllll} & & & & \text { Area\% Name }\end{array}$

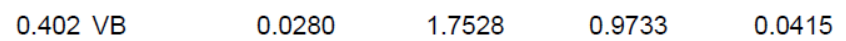

$\begin{array}{lllll}0.541 \mathrm{VV} & 0.0230 & 6.9941 & 4.5424 & 0.1656\end{array}$

$\begin{array}{lllll}0.574 \mathrm{VV} & 0.0206 & 2.7747 & 1.9542 & 0.0657\end{array}$

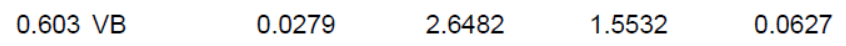

$\begin{array}{lllll}0.955 \text { BV } & 0.0566 & 14.3102 & 3.3642 & 0.3388\end{array}$

$\begin{array}{lllll}1.027 \mathrm{VV} & 0.0281 & 2.2239 & 1.0781 & 0.0527\end{array}$

$\begin{array}{lllll}1.050 \text { VB } & 0.0262 & 1.7251 & 0.9484 & 0.0408\end{array}$

$\begin{array}{lllll}1.650 \mathrm{BV} & 0.0550 & 4.4392 & 0.9768 & 0.1051\end{array}$

$\begin{array}{lllll}1.722 \mathrm{VV} & 0.0401 & 2.8998 & 0.9371 & 0.0687\end{array}$

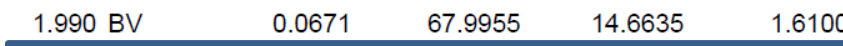

\begin{tabular}{|lrrrr|}
\hline $2.429 \mathrm{BV}$ & 0.0768 & 2249.1147 & 454.2921 & 53.2533 \\
\hline $2.660 \mathrm{VV}$ & 0.0253 & 2.4295 & 1.4673 & 0.0575 \\
$2.738 \mathrm{VB}$ & 0.0476 & 1.7874 & 0.5134 & 0.0423
\end{tabular}

\begin{tabular}{|lrrrr|}
\hline $2.891 \mathrm{VV}$ & 0.0400 & 2.6132 & 0.9239 & 0.0619 \\
\hline $3.263 \mathrm{VV}$ & 0.1572 & 1507.3801 & 147.5885 & 35.6909 \\
\hline $3.628 \mathrm{VV}$ & 0.0560 & 10.6381 & 2.3889 & 0.2519 \\
$3.733 \mathrm{VV}$ & 0.0371 & 5.3387 & 2.0051 & 0.1264 \\
$3.897 \mathrm{VV}$ & 0.0631 & 7.3908 & 1.5112 & 0.1750 \\
$3.937 \mathrm{VB}$ & 0.0301 & 2.3679 & 1.1465 & 0.0561 \\
$4.008 \mathrm{BV}$ & 0.0231 & 1.8269 & 1.2498 & 0.0433 \\
$4.496 \mathrm{BV}$ & 0.0352 & 2.6793 & 1.0687 & 0.0634 \\
$4.586 \mathrm{VB}$ & 0.0406 & 3.4312 & 1.0949 & 0.0812 \\
$4.935 \mathrm{BV}$ & 0.0337 & 2.1549 & 0.8469 & 0.0510 \\
$5.084 \mathrm{VB}$ & 0.0459 & 4.6895 & 1.3361 & 0.1110 \\
$5.254 \mathrm{BB}$ & 0.0339 & 2.4332 & 1.0160 & 0.0576 \\
$5.412 \mathrm{VV}$ & 0.0505 & 2.4339 & 0.5978 & 0.0576 \\
$5.514 \mathrm{VB}$ & 0.0384 & 4.0682 & 1.4640 & 0.0963 \\
$6.194 \mathrm{VB}$ & 0.0500 & 2.1024 & 0.5223 & 0.0498 \\
$7.112 \mathrm{BV}$ & 0.0455 & 2.4547 & 0.7065 & 0.0581 \\
$7.334 \mathrm{VB}$ & 0.3356 & 55.6474 & 1.9577 & 1.3176 \\
$9.701 \mathrm{BBA}$ & 0.3359 & 12.7573 & 0.4484 & 0.3021 \\
& 0.8416 & 228.1287 & 3.1890 & 5.4015 \\
& Sum & 4223.4270 & & \\
\hline
\end{tabular}




\begin{tabular}{|c|c|c|c|c|c|}
\hline \multicolumn{5}{|c|}{ APS Group SFC Report } & \multirow{2}{*}{ এb৮Vie } \\
\hline Signal: & B, Sig $=254,1$ & Ref $=360,100$ & & & \\
\hline RT [min] Type & Width [min] & Area & Height & Area\% Name & \\
\hline $0.458 \mathrm{BV}$ & 0.0274 & 1.5805 & 0.8614 & 0.0878 & \\
\hline $0.493 \mathrm{VV}$ & 0.0309 & 3.1469 & 1.4165 & 0.1748 & \\
\hline $0.539 \mathrm{VB}$ & 0.0248 & 6.5965 & 4.0968 & 0.3663 & \\
\hline $0.811 \mathrm{BV}$ & 0.0419 & 3.5493 & 1.1853 & 0.1971 & \\
\hline 0.679 VB & 0.0564 & 3.6049 & 0.8029 & 0.2002 & \\
\hline $0.837 \mathrm{BB}$ & 0.0302 & 1.5265 & 0.8024 & 0.0848 & \\
\hline $0.247 \mathrm{BB}$ & 0.0563 & 5.4818 & 1.4104 & 0.3044 & \\
\hline $1.028 \mathrm{BV}$ & 0.0495 & 1.6169 & 0.4242 & 0.0888 & \\
\hline $1.464 \mathrm{BB}$ & 0.0814 & 2.3921 & 0.3751 & 0.1328 & \\
\hline $1.989 \mathrm{VB}$ & 0.0689 & 118.1210 & 26.0562 & 6.5596 & \\
\hline $2.429 \mathrm{BV}$ & 0.0774 & 978.4331 & 195.5605 & 54.3350 & \\
\hline $2.697 \mathrm{VV}$ & 0.0458 & 1.5842 & 0.4528 & 0.0880 & \\
\hline $3.263 \mathrm{VV}$ & 0.1582 & 664.5590 & 65.0255 & 36.9047 & \\
\hline $3.731 \mathrm{VB}$ & 0.0581 & 2.6139 & 0.6474 & 0.1452 & \\
\hline $4.008 \mathrm{BB}$ & 0.0477 & 1.4083 & 0.4035 & 0.0782 & \\
\hline $4.285 \mathrm{BB}$ & 0.0467 & 1.2526 & 0.3676 & 0.0696 & \\
\hline $5.414 \mathrm{BB}$ & 0.0725 & 3.2753 & 0.5748 & 0.1819 & \\
\hline & Sum & 1800.7427 & & & \\
\hline
\end{tabular}

Enriched Sample (3): 


\section{APS Group SFC Report}

abbvie

Sample name:

Instrument:

Acq. method: Description:

Data file:

Injection date:
10668205-1504

Aurora-2

05_50_MEOH_3ML_10MIN_150BAR.M

Column Position 3: ChiralPak AS-H

C:IChem32/11Datal171026_162700 2017-10-26 16-29-27\171026042656.D

10/26/2017 4:33:21 PM
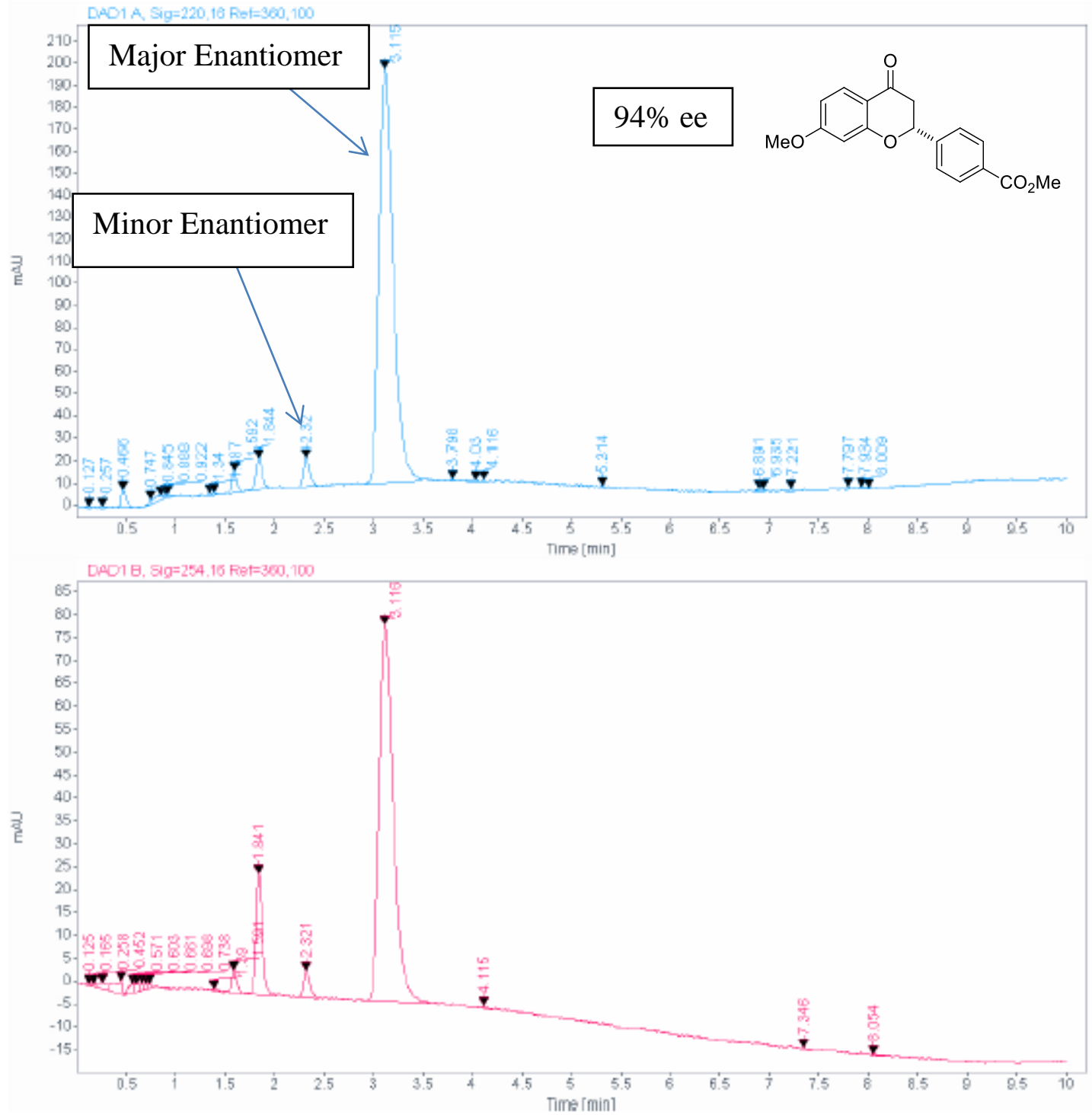


\begin{tabular}{|c|c|c|c|c|c|}
\hline \multicolumn{5}{|c|}{ APS Group SFC Report } & \\
\hline \multicolumn{6}{|c|}{ Signal: $\quad$ DAD1 A, Sig $=220,16$ Ref $=360,100$} \\
\hline RT [min] Type & Width [min] & Area & Height & Area\% Name & \\
\hline $0.127 \mathrm{BV}$ & 0.0366 & 2.0576 & 0.7848 & 0.0970 & \\
\hline $0.257 \mathrm{VB}$ & 0.0334 & 1.8843 & 0.7735 & 0.0888 & \\
\hline $0.466 \mathrm{BB}$ & 0.0460 & 27.4028 & 8.0004 & 1.2916 & \\
\hline $0.747 \mathrm{BV}$ & 0.0337 & 5.1092 & 2.2342 & 0.2408 & \\
\hline $0.845 \mathrm{VV}$ & 0.0699 & 13.4087 & 2.3739 & 0.6320 & \\
\hline $0.888 \mathrm{~V}$ & 0.0337 & 4.4848 & 1.8577 & 0.2114 & \\
\hline 0.922 VB & 0.0224 & 2.1597 & 1.4485 & 0.1018 & \\
\hline $1.340 \mathrm{BV}$ & 0.0272 & 1.7945 & 0.8660 & 0.0846 & \\
\hline $1.387 \mathrm{VV}$ & 0.0299 & 2.0535 & 1.0473 & 0.0968 & \\
\hline $1.592 \mathrm{BV}$ & 0.0510 & 32.1642 & 9.8708 & 1.5160 & \\
\hline $1.844 \mathrm{BV}$ & 0.0689 & 62.6761 & 14.3725 & 2.9541 & \\
\hline $2.320 \mathrm{BV}$ & 0.0726 & 60.0891 & 13.0726 & 2.8322 & \\
\hline 3.115 BV & 0.1534 & 1883.8190 & 187.2324 & 88.7896 & \\
\hline $3.798 \mathrm{BV}$ & 0.0293 & 1.7044 & 0.8520 & 0.0803 & \\
\hline $4.030 \mathrm{BB}$ & 0.0529 & 3.4501 & 0.8228 & 0.1626 & \\
\hline $4.116 \mathrm{BV}$ & 0.0309 & 2.2324 & 1.0462 & 0.1052 & \\
\hline $5.314 \mathrm{BV}$ & 0.0363 & 2.0047 & 0.7241 & 0.0945 & \\
\hline $6.891 \mathrm{BV}$ & 0.0374 & 2.7275 & 1.0133 & 0.1286 & \\
\hline $6.935 \mathrm{VV}$ & 0.0235 & 1.7764 & 1.0639 & 0.0837 & \\
\hline $7.221 \mathrm{VV}$ & 0.0347 & 2.9029 & 1.1801 & 0.1368 & \\
\hline $7.797 \mathrm{VV}$ & 0.0315 & 2.0011 & 0.9169 & 0.0943 & \\
\hline $7.934 \mathrm{BV}$ & 0.0375 & 1.8794 & 0.6951 & 0.0886 & \\
\hline $8.009 \mathrm{VB}$ & 0.0465 & 1.8837 & 0.5561 & 0.0888 & \\
\hline & Sum & 2121.6860 & & & \\
\hline
\end{tabular}

Signal: DAD1 B, Sig $=254,16$ Ref $=360,100$

\begin{tabular}{lrrrr} 
RT [min] Type & Width [min] & Area & Height & Area\% Name \\
$0.125 \mathrm{BV}$ & 0.0382 & 1.4190 & 0.4992 & 0.1343 \\
$0.165 \mathrm{VV}$ & 0.0379 & 1.7924 & 0.7247 & 0.1696 \\
$0.258 \mathrm{VV}$ & 0.0868 & 9.8644 & 1.3897 & 0.9334 \\
$0.452 \mathrm{VB}$ & 0.0734 & 16.7111 & 2.9375 & 1.5813 \\
$0.571 \mathrm{BV}$ & 0.0583 & 8.7527 & 1.9918 & 0.8282 \\
$0.603 \mathrm{VV}$ & 0.0314 & 4.0289 & 1.8501 & 0.3812 \\
$0.661 \mathrm{VV}$ & 0.0404 & 4.2300 & 1.4780 & 0.4003 \\
$0.698 \mathrm{VV}$ & 0.0353 & 3.1579 & 1.3024 & 0.2988 \\
$0.738 \mathrm{VB}$ & 0.0315 & 2.2652 & 1.0358 & 0.2143 \\
$1.390 \mathrm{VV}$ & 0.0554 & 2.6328 & 0.6092 & 0.2491 \\
$1.591 \mathrm{VB}$ & 0.0549 & 17.8648 & 4.9785 & 1.6905 \\
$1.841 \mathrm{BV}$ & 0.0683 & 116.3209 & 26.4696 & 11.0070 \\
\hline $2.321 \mathrm{BV}$ & 0.0720 & 26.8087 & 5.7967 & 2.5368 \\
$3.116 \mathrm{BV}$ & 0.1557 & 836.2499 & 82.1706 & 79.1311 \\
\hline $4.115 \mathrm{BB}$ & 0.0447 & 1.4822 & 0.4473 & 0.1403 \\
$7.346 \mathrm{BB}$ & 0.0455 & 1.2616 & 0.3727 & 0.1194 \\
$8.054 \mathrm{BB}$ & 0.0636 & 1.9485 & 0.3945 & 0.1844 \\
& Sum & 1056.7910 & & \\
\hline
\end{tabular}

II. Amine Hydrochloride

Enantiomeric Mixture (2 and S4): 


\section{APS Group SFC Report}

\section{abbvie}

Sample name: Instrument:

Acq. method: Description:

Data file:

Injection date: $10688205-3347-r a c$

Aurora-2

Vial Location: 3
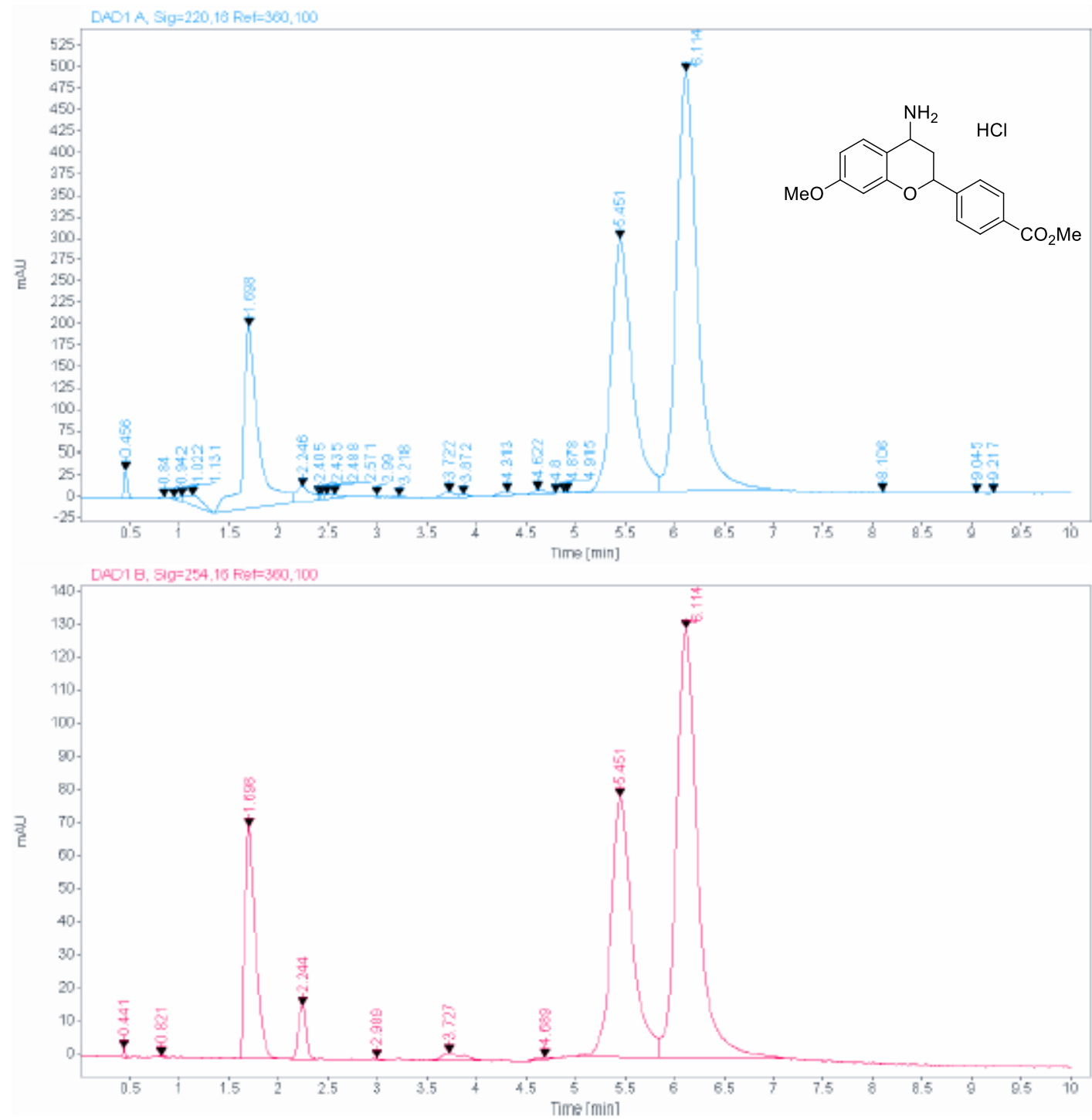


\section{APS Group SFC Report}

Signal: DAD1 A, Sig=220,16 Ref $=360,100$

\begin{tabular}{crrrc} 
RT [min] Type & Width [min] & Area & Height & Area\% Name \\
$0.456 \mathrm{BB}$ & 0.0381 & 78.0005 & 32.3582 & 0.5455 \\
$0.840 \mathrm{BB}$ & 0.0505 & 2.7427 & 0.7192 & 0.0192 \\
$0.942 \mathrm{BV}$ & 0.0390 & 5.4364 & 2.1854 & 0.0380 \\
$1.022 \mathrm{WV}$ & 0.0489 & 22.0407 & 6.1426 & 0.1542 \\
$1.131 \mathrm{VB}$ & 0.1490 & 138.6698 & 11.7242 & 0.9699 \\
$1.698 \mathrm{BV}$ & 0.1389 & 2238.2686 & 210.8097 & 15.6546 \\
$2.246 \mathrm{WV}$ & 0.1421 & 186.2992 & 17.9542 & 1.3030 \\
$2.405 \mathrm{WV}$ & 0.0231 & 11.5114 & 6.3781 & 0.0805 \\
$2.435 \mathrm{WV}$ & 0.0319 & 13.3225 & 5.9921 & 0.0932 \\
$2.488 \mathrm{WV}$ & 0.0576 & 23.2760 & 4.9779 & 0.1628 \\
$2.571 \mathrm{VB}$ & 0.0640 & 17.9859 & 3.6209 & 0.1258 \\
$2.990 \mathrm{BV}$ & 0.0456 & 4.0171 & 1.1832 & 0.0281 \\
$3.218 \mathrm{BB}$ & 0.0800 & 7.7941 & 1.1814 & 0.0545 \\
$3.722 \mathrm{VV}$ & 0.1091 & 52.7002 & 5.8493 & 0.3686 \\
$3.872 \mathrm{VB}$ & 0.0892 & 20.8730 & 2.9623 & 0.1460 \\
$4.313 \mathrm{BB}$ & 0.1282 & 44.7621 & 4.2058 & 0.3131 \\
$4.622 \mathrm{BV}$ & 0.1232 & 51.3154 & 5.1534 & 0.3589 \\
$4.800 \mathrm{WV}$ & 0.0276 & 2.0233 & 1.0912 & 0.0142 \\
$4.878 \mathrm{WV}$ & 0.0544 & 3.3912 & 0.7850 & 0.0237 \\
$4.915 \mathrm{VB}$ & 0.0344 & 1.7968 & 0.6902 & 0.0126 \\
\hline $5.451 \mathrm{BV}$ & 0.2186 & 4250.6284 & 292.4522 & 29.7291 \\
$6.114 \mathrm{VB}$ & 0.2206 & 7115.1143 & 486.4535 & 49.7634 \\
\hline $8.106 \mathrm{BV}$ & 0.0317 & 1.6825 & 0.6840 & 0.0118 \\
$9.045 \mathrm{WV}$ & 0.0525 & 1.6826 & 0.4964 & 0.0118 \\
$9.217 \mathrm{BV}$ & 0.0478 & 2.5440 & 0.6938 & 0.0178 \\
& Sum & 14297.8785 & & \\
\hline
\end{tabular}

Signal: $\quad$ DAD1 B, Sig $=254,16$ Ref $=360,100$

\begin{tabular}{|c|c|c|c|c|}
\hline RT [min] Type & Width [min] & Area & Height & Area\% Name \\
\hline $0.441 \mathrm{BB}$ & 0.0206 & 3.6137 & 2.8846 & 0.0954 \\
\hline $0.821 \mathrm{BB}$ & 0.0509 & 1.6832 & 0.4282 & 0.0445 \\
\hline $1.698 \mathrm{VB}$ & 0.1021 & 530.2116 & 70.2406 & 14.0047 \\
\hline $2.244 \mathrm{BB}$ & 0.0875 & 87.2715 & 16.0436 & 2.3051 \\
\hline $2.989 \mathrm{VB}$ & 0.0446 & 1.2449 & 0.3864 & 0.0329 \\
\hline $3.727 \mathrm{VB}$ & 0.1734 & 31.3777 & 2.1734 & 0.8288 \\
\hline $4.689 \mathrm{BB}$ & 0.1203 & 5.3116 & 0.5467 & 0.1403 \\
\hline $5.451 \mathrm{~W}$ & 0.2241 & 1173.7076 & 78.6832 & 31.0018 \\
\hline \multirow[t]{2}{*}{$6.114 \mathrm{VV}$} & 0.2278 & 1951.5369 & 129.5454 & 51.5467 \\
\hline & Sum & 3785.9587 & & \\
\hline
\end{tabular}

Enantioenriched Sample (2): 


\section{APS Group SFC Report}

abbvie

Sample name:

Instrument:

Acq. method:

Description:

Data file:

Injection date:
10668205-1364

Aurora-2

05_30_MEOH-DEA_3ML_10MIN_150BAR.M

Column Position 1: ChiralCel OD-H

C:IChem32/1VDatal171018_105433 2017-10-18 10-56-08\171018105422.D

10/18/2017 11:14:24 AM
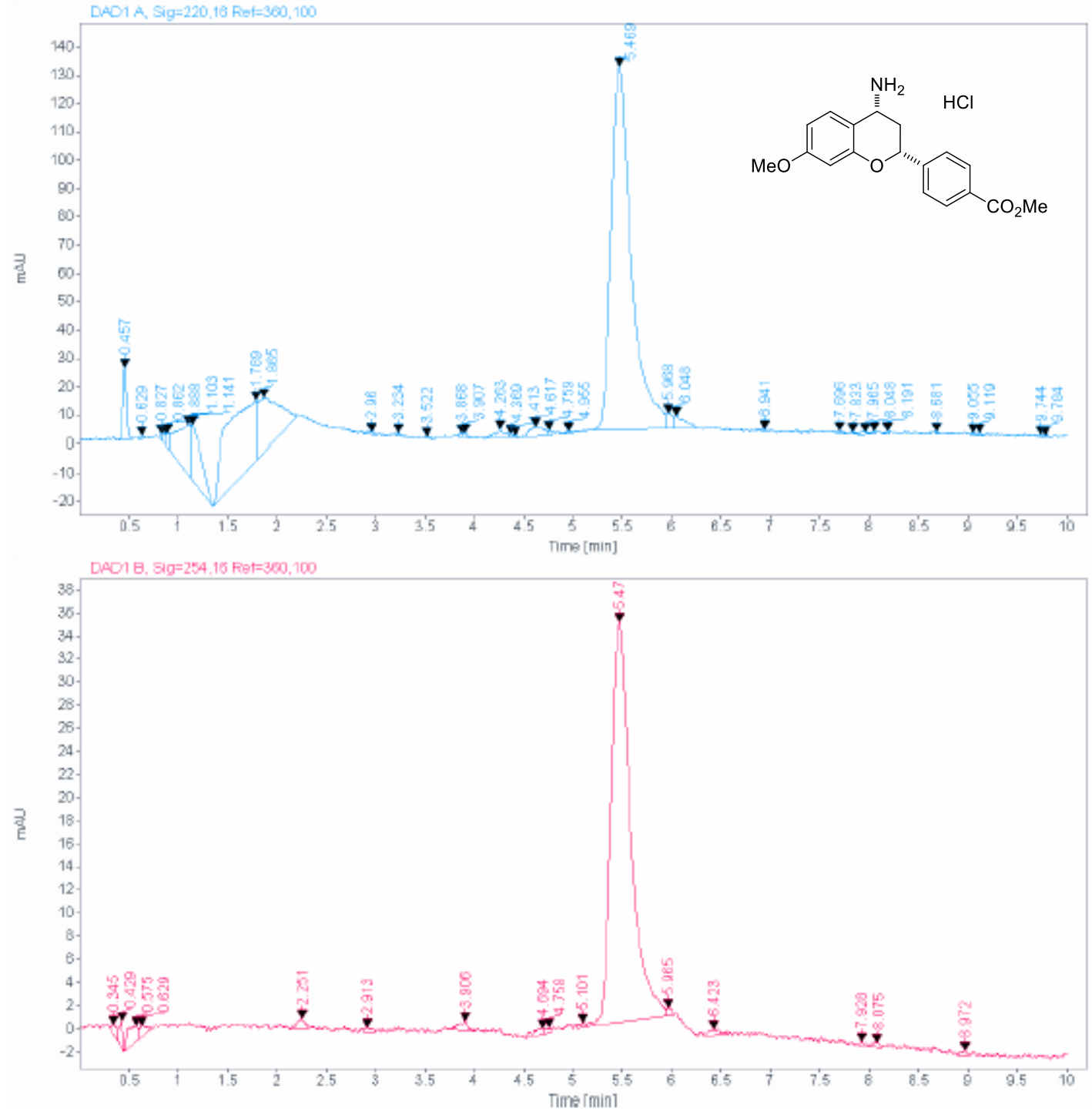


\section{APS Group SFC Report}

Signal: DAD1 A, Sig=220,16 Ref $=360,100$

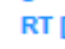

III. Amide

Enantiomeric Mixture (7 and S5): 


\section{APS Group SFC Report}

abbie

Sample name: Instrument:

Acq. method: Description:

Data file:

Injection date: 10688205-1550-rac

Aurora-2

05_30_MEOH_3ML_10MIN_150BAR.M

Column Position 3: ChiralPak AS-H

C:IChem32/11Datal171026_102741 2017-10-26 10-28-211171026102732.D

10/26/2017 10:32:16 AM
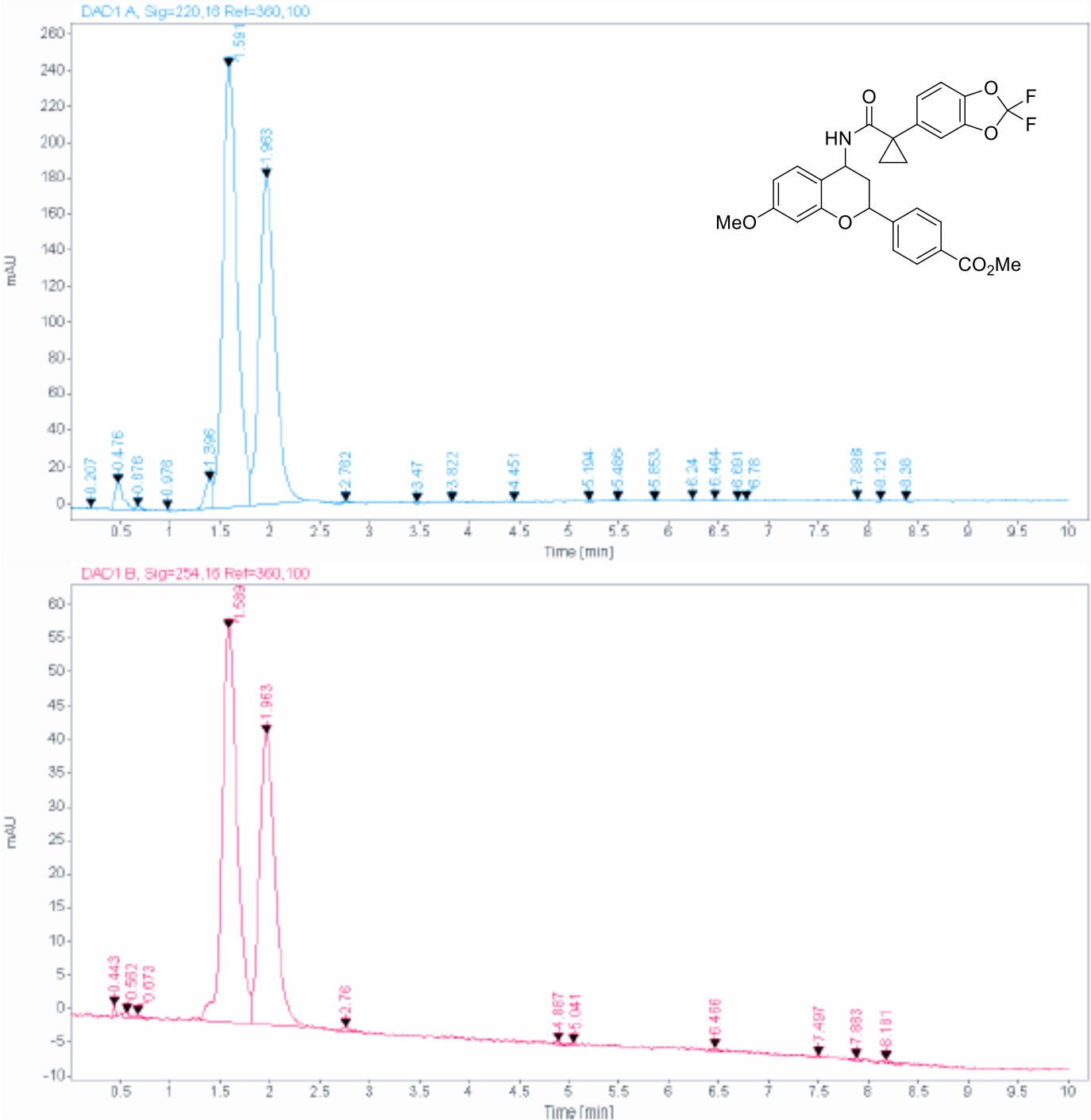


\section{APS Group SFC Report}

\begin{tabular}{|c|c|c|c|c|c|}
\hline \multirow{2}{*}{$\begin{array}{l}\text { Signal: } \\
\text { RT [min }\end{array}$} & \multicolumn{3}{|c|}{ DAD1 A, Sig=220,16 Ref $=360,100$} & \multirow[b]{2}{*}{ Height } & \multirow[b]{2}{*}{ Area\% Name } \\
\hline & ] Type & Width [min] & Area & & \\
\hline 0.207 & 7 BV & 0.0459 & 2.0950 & 0.5698 & 0.0451 \\
\hline 0.476 & $3 \mathrm{BV}$ & 0.0715 & 81.9893 & 14.8381 & 1.7632 \\
\hline 0.676 & 3 VB & 0.0568 & 9.3886 & 2.0757 & 0.2019 \\
\hline 0.976 & $3 \mathrm{BV}$ & 0.0470 & 1.9741 & 0.5623 & 0.0425 \\
\hline 1.396 & $3 \mathrm{BV}$ & 0.0792 & 84.9421 & 15.6922 & 1.8267 \\
\hline 1.591 & $\mathrm{ivV}$ & 0.1557 & 2457.9495 & 243.5722 & 52.8601 \\
\hline 1.963 & 3 VB & 0.1658 & 1976.4879 & 180.3882 & 42.5059 \\
\hline 2.762 & $2 \mathrm{BV}$ & 0.0594 & 5.8174 & 1.2481 & 0.1251 \\
\hline 3.470 & BV & 0.0477 & 2.3519 & 0.6579 & 0.0506 \\
\hline 3.822 & $2 \mathrm{BV}$ & 0.0344 & 1.9484 & 0.7720 & 0.0419 \\
\hline 4.451 & $\mathrm{VV}$ & 0.0414 & 2.1851 & 0.6640 & 0.0470 \\
\hline 5.194 & $4 \mathrm{BV}$ & 0.0407 & 2.3116 & 0.7992 & 0.0497 \\
\hline 5.486 & $3 \mathrm{VV}$ & 0.0564 & 3.0306 & 0.7020 & 0.0652 \\
\hline 5.853 & $3 \mathrm{BV}$ & 0.0381 & 2.0251 & 0.7356 & 0.0436 \\
\hline 6.240 & $\mathrm{BV}$ & 0.0309 & 2.1999 & 0.9191 & 0.0473 \\
\hline 6.464 & $4 \mathrm{VV}$ & 0.0431 & 2.8948 & 0.8630 & 0.0623 \\
\hline 6.691 & $\mathrm{WV}$ & 0.0383 & 1.8571 & 0.6924 & 0.0399 \\
\hline 6.780 & VB & 0.0420 & 2.7029 & 0.8305 & 0.0581 \\
\hline 7.886 & $8 \mathrm{VB}$ & 0.0363 & 1.9221 & 0.7681 & 0.0413 \\
\hline 8.121 & $1 \mathrm{BV}$ & 0.0320 & 1.9518 & 0.7860 & 0.0420 \\
\hline \multirow{2}{*}{\multicolumn{2}{|c|}{$8.380 \mathrm{BB}$}} & 0.0346 & 1.8897 & 0.6970 & 0.0406 \\
\hline & & Sum & 4649.9148 & & \\
\hline
\end{tabular}

Signal: $\quad$ DAD1 B, Sig $=254,16$ Ref $=360,100$

\begin{tabular}{crrrr} 
RT [min] Type & Width [min] & Area & Height & Area\% Name \\
$0.443 \mathrm{BB}$ & 0.0230 & 2.4984 & 1.7111 & 0.2257 \\
$0.562 \mathrm{VV}$ & 0.0519 & 2.7399 & 0.6958 & 0.2475 \\
$0.673 \mathrm{VB}$ & 0.0569 & 1.9583 & 0.4574 & 0.1769 \\
\hline $1.589 \mathrm{VV}$ & 0.1613 & 612.3860 & 58.4401 & 55.3213 \\
$1.963 \mathrm{VB}$ & 0.1638 & 472.5446 & 43.1507 & 42.6884 \\
\hline $2.760 \mathrm{BB}$ & 0.0680 & 3.1313 & 0.5707 & 0.2829 \\
$4.887 \mathrm{BB}$ & 0.0559 & 1.6471 & 0.3630 & 0.1488 \\
$5.041 \mathrm{BB}$ & 0.0551 & 1.6169 & 0.3843 & 0.1461 \\
$6.466 \mathrm{BB}$ & 0.0680 & 2.3085 & 0.4345 & 0.2085 \\
$7.497 \mathrm{BB}$ & 0.0534 & 1.6514 & 0.4066 & 0.1492 \\
$7.883 \mathrm{BV}$ & 0.0614 & 1.9530 & 0.4186 & 0.1764 \\
$8.181 \mathrm{VV}$ & 0.0573 & 2.5281 & 0.5752 & 0.2284 \\
& Sum & 1106.9634 & & \\
& & & &
\end{tabular}

Enantioenriched Product (7): 


\section{APS Group SFC Report}

abbvie

Sample name: Instrument:

Acq. method:

Description:

Data file:

Injection date: 10668205-1550-ee

Aurora-2

05_30_MEOH_3ML_10MIN_150BAR.M

Column Position 3: ChiralPak AS-H

C:IChem32।11Datal171026_102741 2017-10-26 10-28-21\171026102733.D

10/26/2017 10:46:35 AM
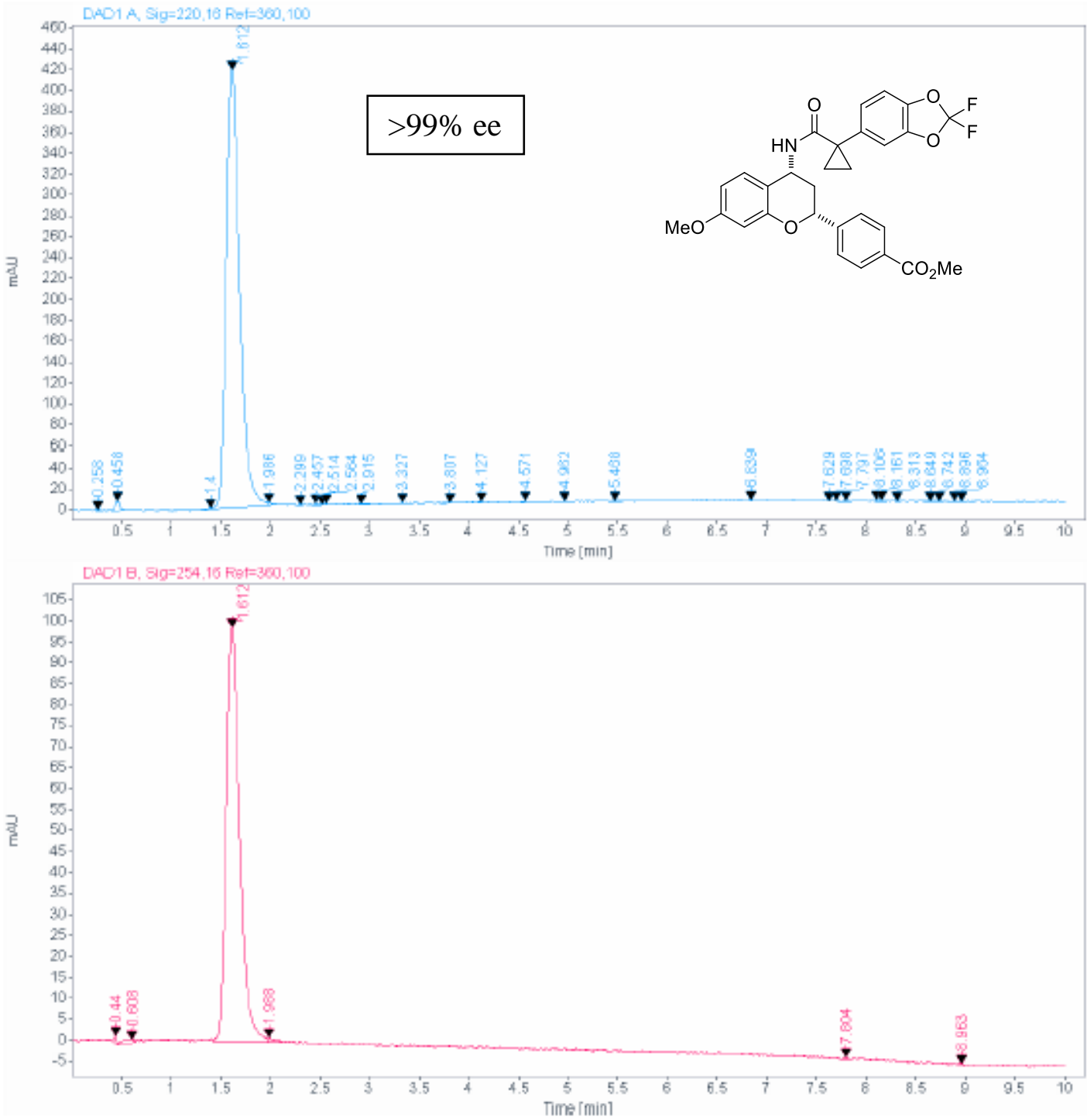


\section{APS Group SFC Report}

\begin{tabular}{|c|c|c|c|c|}
\hline Signal: & $1 \mathrm{~A}, \mathrm{Sig}=220,1$ & Ref $=360,100$ & & \\
\hline RT [min] Type & Width [min] & Area & Height & Area\% Name \\
\hline $0.258 \mathrm{VB}$ & 0.0330 & 1.6869 & 0.6565 & 0.0423 \\
\hline $0.458 \mathrm{VB}$ & 0.0468 & 26.8084 & 8.7424 & 0.6717 \\
\hline $1.400 \mathrm{BV}$ & 0.0347 & 2.6512 & 1.0784 & 0.0684 \\
\hline $1.612 \mathrm{VV}$ & 0.1430 & 3902.0186 & 417.8166 & 97.7663 \\
\hline $1.986 \mathrm{VV}$ & 0.0366 & 6.2899 & 2.3951 & 0.1576 \\
\hline $2.299 \mathrm{BV}$ & 0.0333 & 1.7091 & 0.7581 & 0.0428 \\
\hline $2.457 \mathrm{BV}$ & 0.0290 & 2.0665 & 1.0065 & 0.0518 \\
\hline $2.514 \mathrm{WV}$ & 0.0362 & 2.5354 & 0.8650 & 0.0635 \\
\hline $2.564 \mathrm{VV}$ & 0.0369 & 2.7720 & 1.0449 & 0.0695 \\
\hline $2.915 \mathrm{BB}$ & 0.0514 & 2.5176 & 0.6768 & 0.0631 \\
\hline $3.327 \mathrm{VB}$ & 0.0402 & 2.1317 & 0.7979 & 0.0534 \\
\hline $3.807 \mathrm{BV}$ & 0.0481 & 2.2684 & 0.5863 & 0.0568 \\
\hline 4.127 BV & 0.0379 & 2.3827 & 0.8455 & 0.0597 \\
\hline $4.571 \mathrm{BV}$ & 0.0333 & 2.3061 & 0.9497 & 0.0578 \\
\hline $4.962 \mathrm{BB}$ & 0.0396 & 1.7884 & 0.6215 & 0.0448 \\
\hline $5.468 \mathrm{BV}$ & 0.0507 & 2.9194 & 0.7614 & 0.0731 \\
\hline $6.839 \mathrm{BV}$ & 0.0292 & 1.9063 & 1.0017 & 0.0478 \\
\hline $7.629 \mathrm{BV}$ & 0.0383 & 1.7691 & 0.6381 & 0.0443 \\
\hline $7.698 \mathrm{VB}$ & 0.0350 & 2.3779 & 0.8683 & 0.0596 \\
\hline $7.797 \mathrm{BB}$ & 0.0449 & 3.1543 & 0.9451 & 0.0790 \\
\hline 8.106 BV & 0.0269 & 1.8926 & 1.0100 & 0.0474 \\
\hline $8.161 \mathrm{~W}$ & 0.0341 & 2.5052 & 1.0386 & 0.0628 \\
\hline $8.313 \mathrm{VV}$ & 0.0358 & 1.7868 & 0.6557 & 0.0448 \\
\hline $8.649 \mathrm{VV}$ & 0.0481 & 3.7396 & 1.0351 & 0.0937 \\
\hline $8.742 \mathrm{WV}$ & 0.0367 & 2.3167 & 0.8270 & 0.0580 \\
\hline $8.896 \mathrm{VV}$ & 0.0333 & 2.1650 & 0.8934 & 0.0542 \\
\hline \multirow[t]{2}{*}{$8.964 \mathrm{VV}$} & 0.0349 & 2.7046 & 1.1296 & 0.0678 \\
\hline & Sum & 3991.1703 & & \\
\hline
\end{tabular}

\begin{tabular}{lrrrr}
$\begin{array}{l}\text { Signal: } \\
\text { RT [min] Type }\end{array}$ & Width [min] & Area & Height & \multicolumn{1}{c}{ Area\% Name } \\
0.440 BB & 0.0262 & 2.9933 & 1.7287 & 0.3172 \\
$0.608 \mathrm{BV}$ & 0.1111 & 7.2897 & 0.8095 & 0.7724 \\
$1.612 \mathrm{VV}$ & 0.1426 & 926.5792 & 98.6654 & 98.1779 \\
$1.988 \mathrm{VV}$ & 0.0573 & 4.0759 & 0.9267 & 0.4319 \\
$7.804 \mathrm{BB}$ & 0.0477 & 1.4578 & 0.4176 & 0.1545 \\
$8.963 \mathrm{BB}$ & 0.0443 & 1.3803 & 0.4316 & 0.1463 \\
& Sum & 943.7762 & &
\end{tabular}


NMR Spectra 


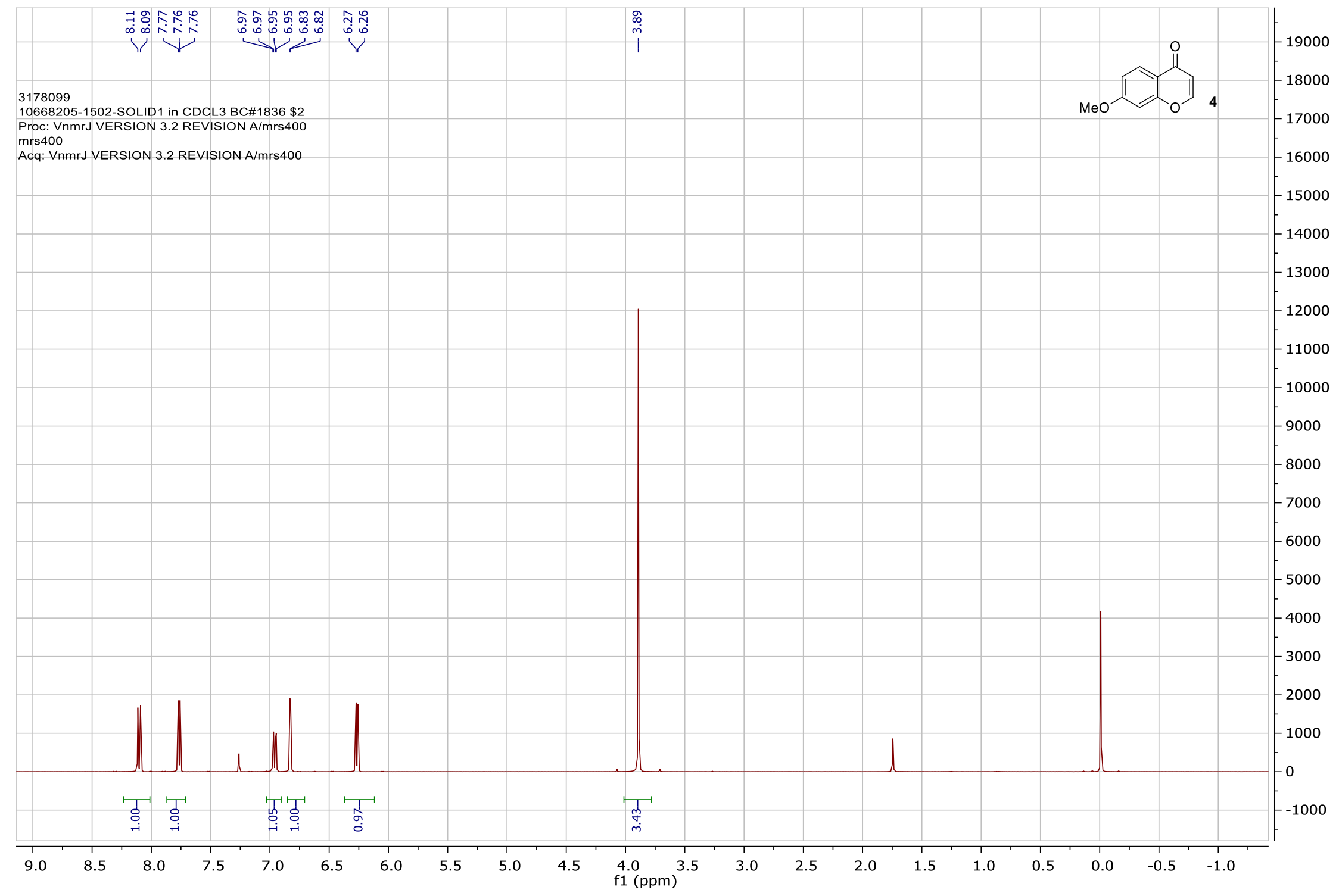




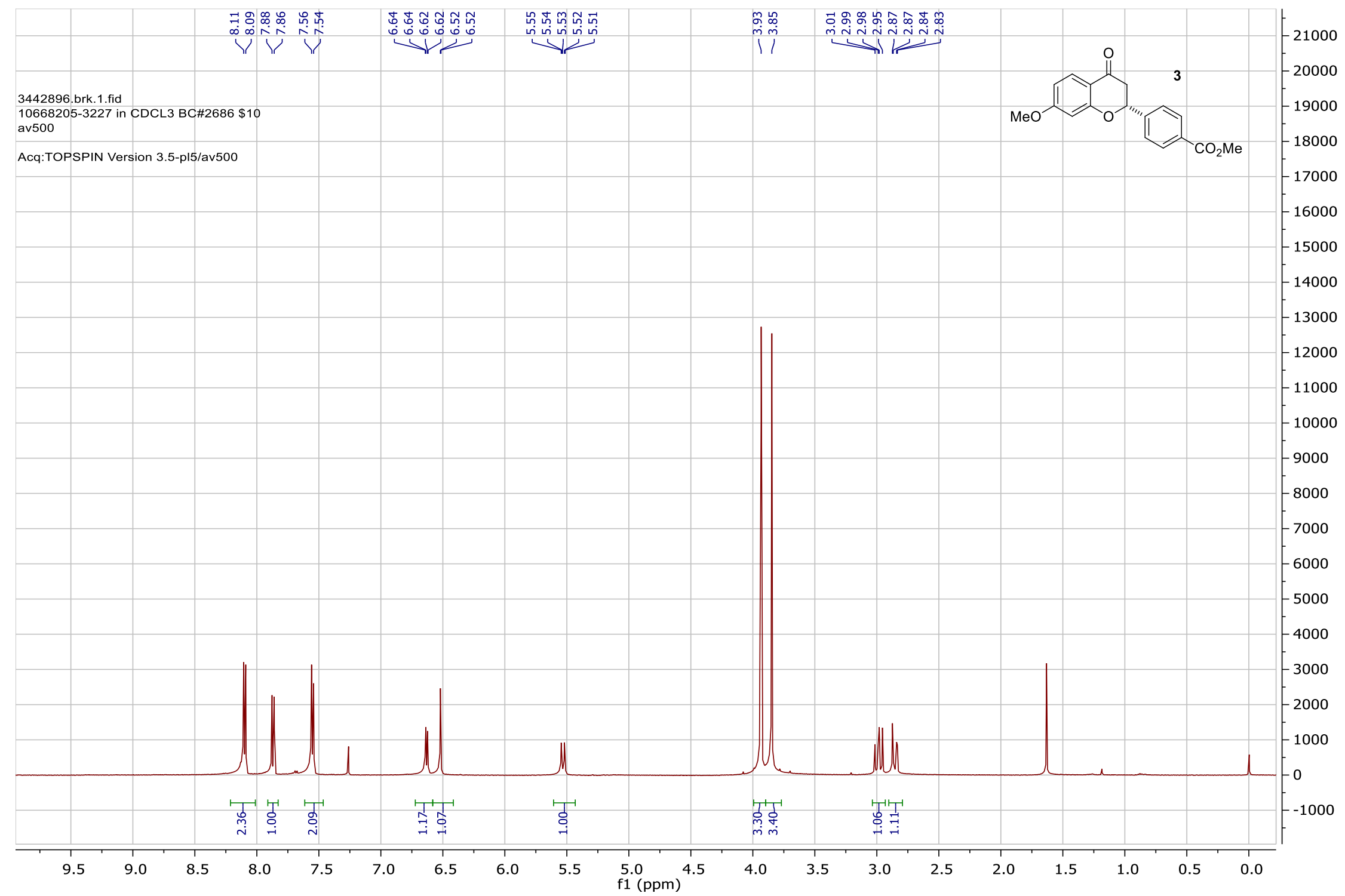




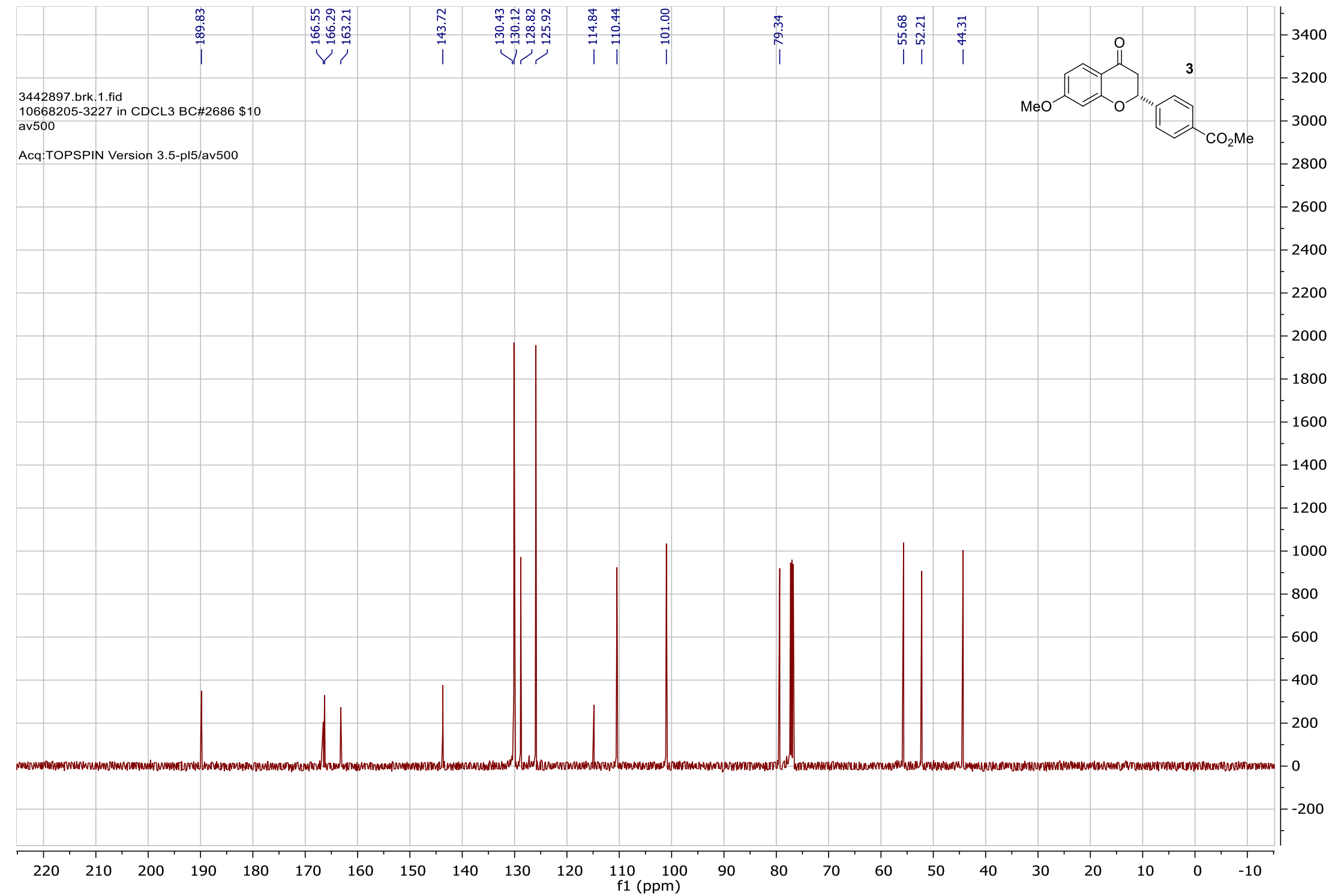




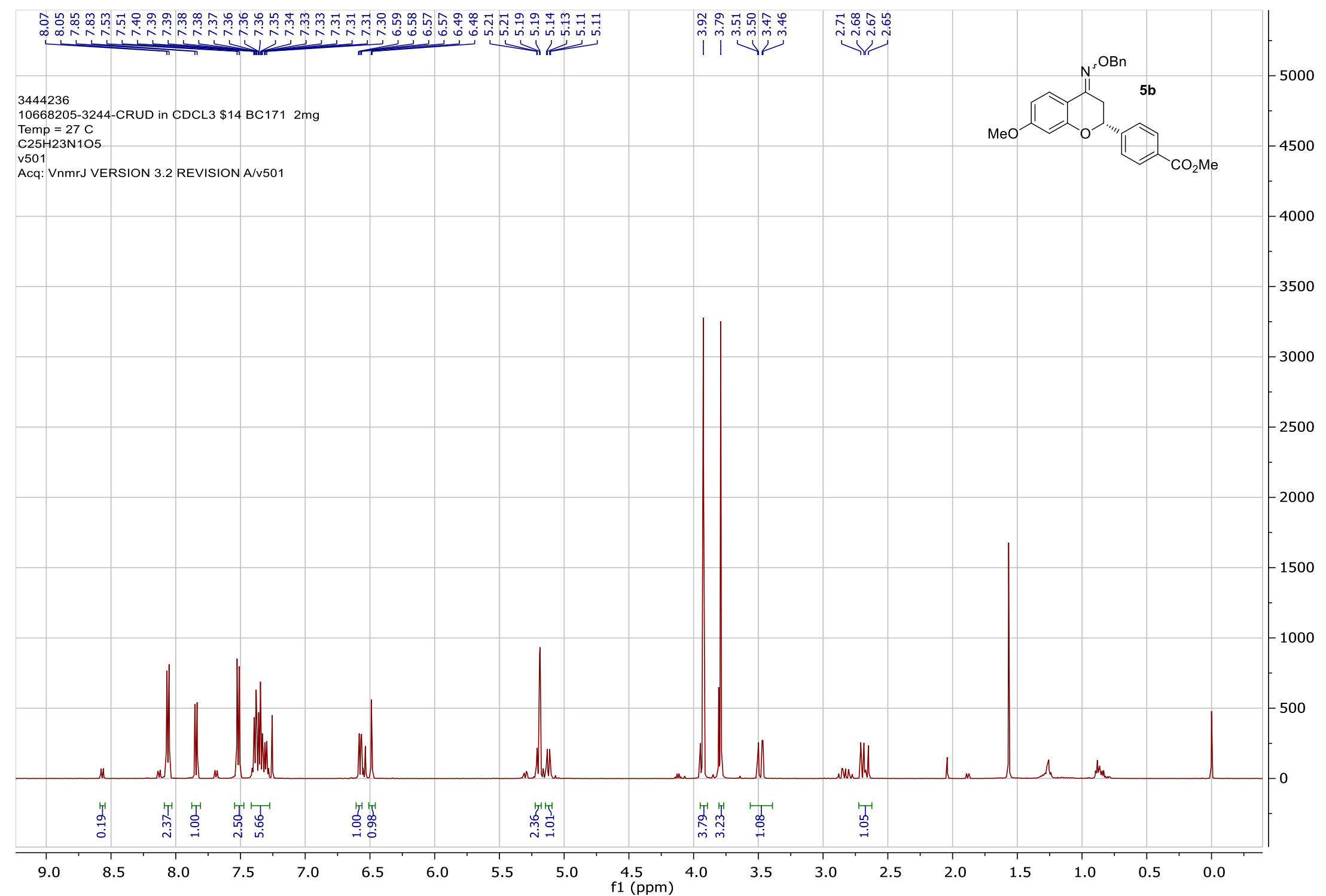




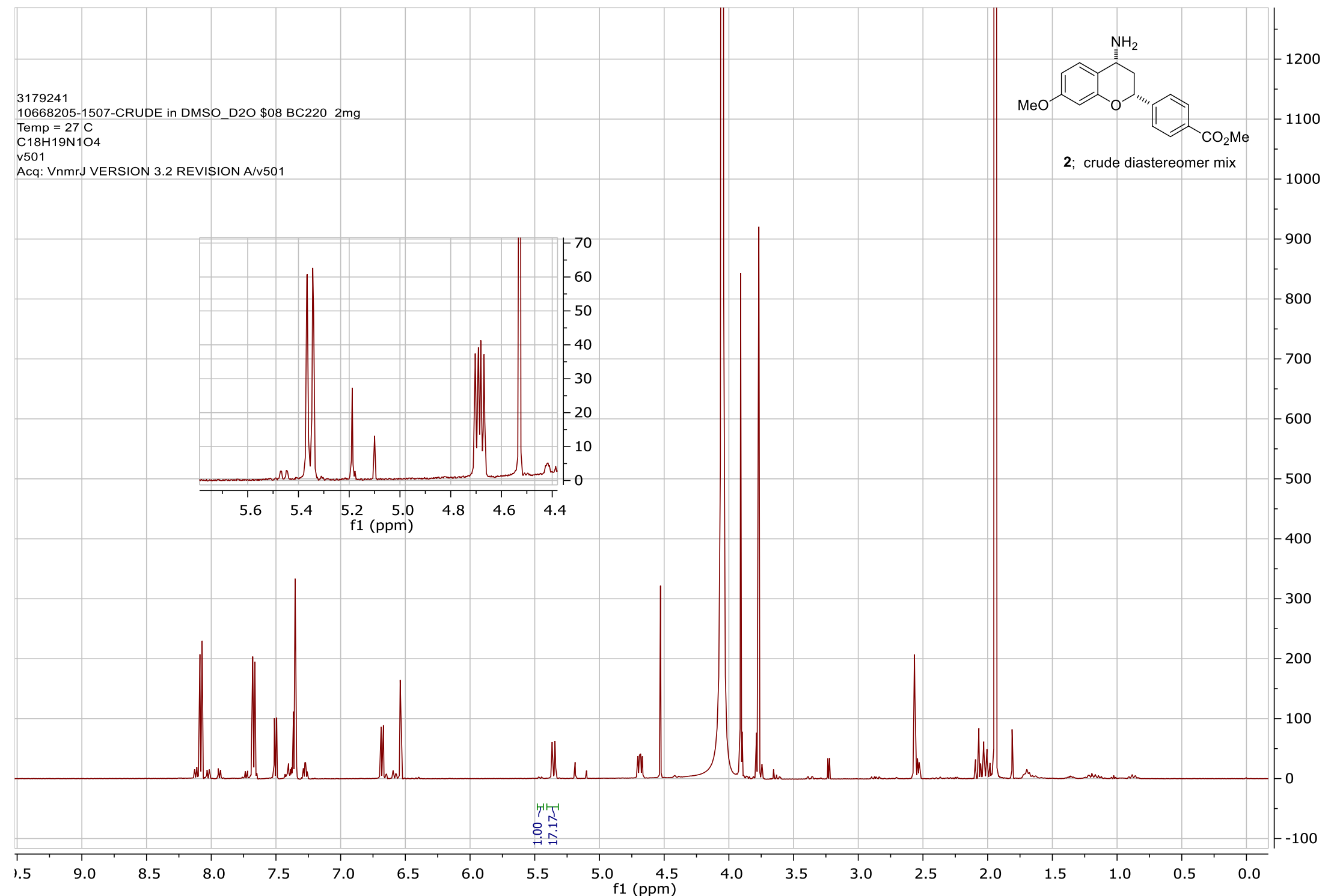




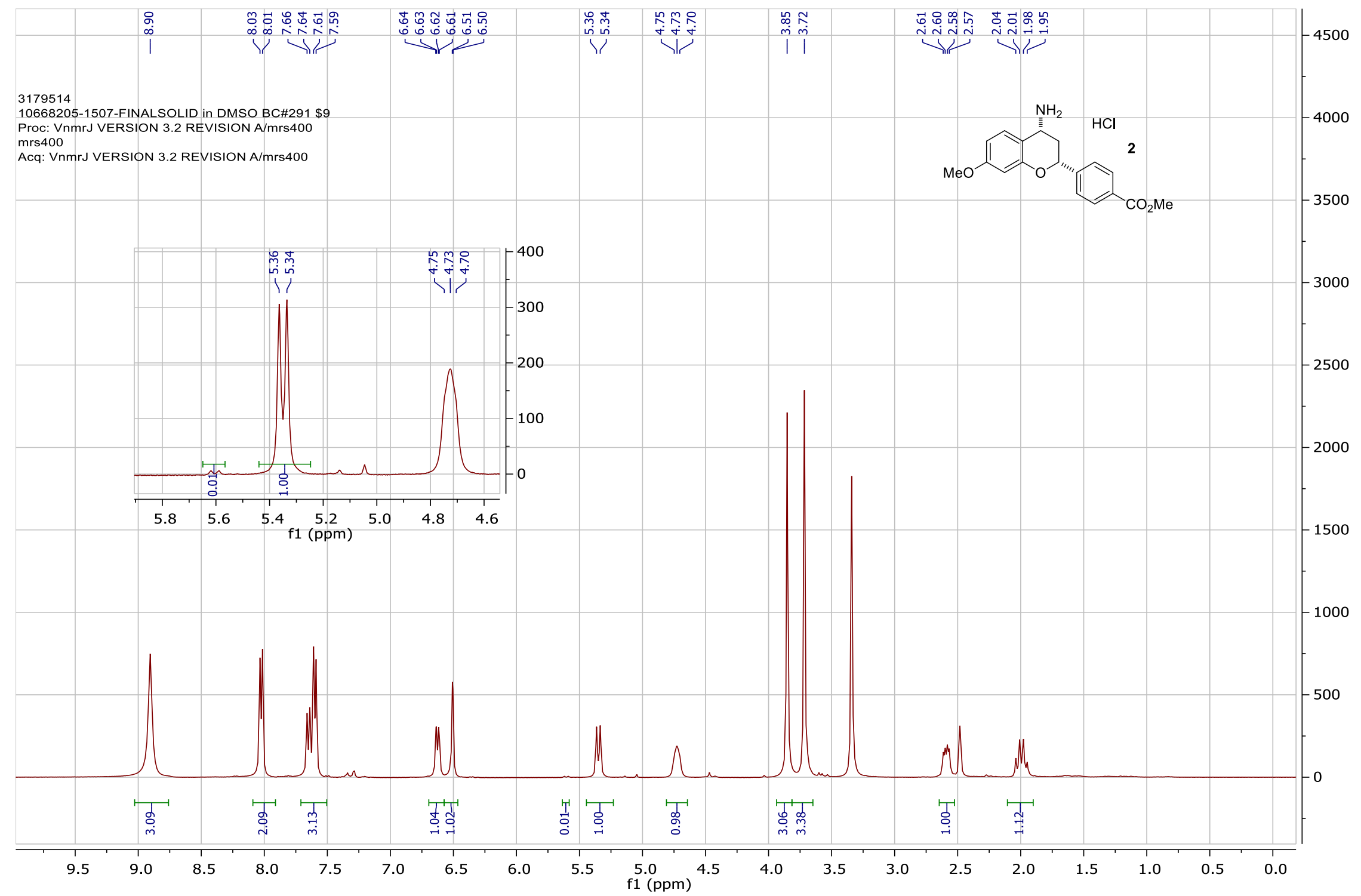




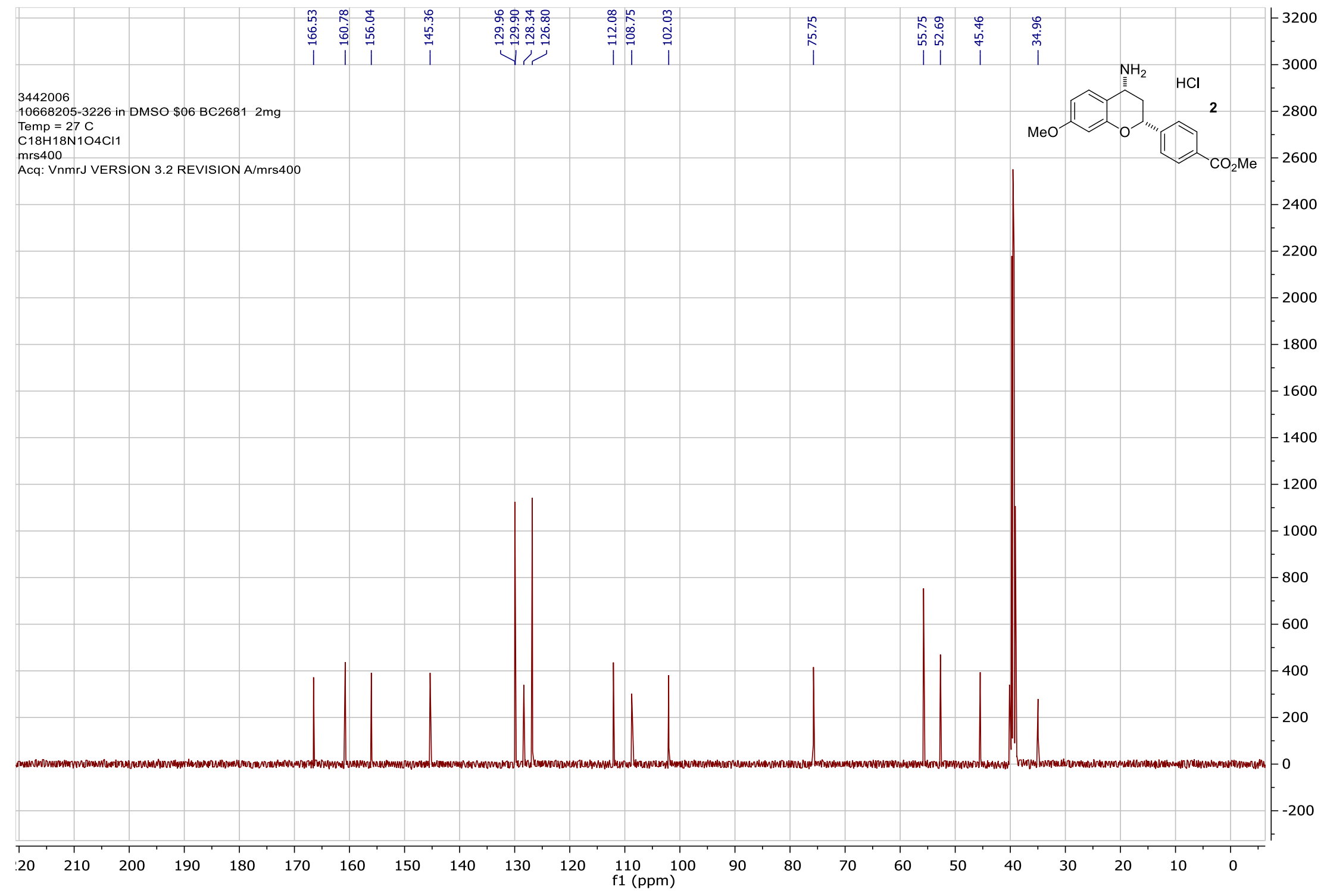




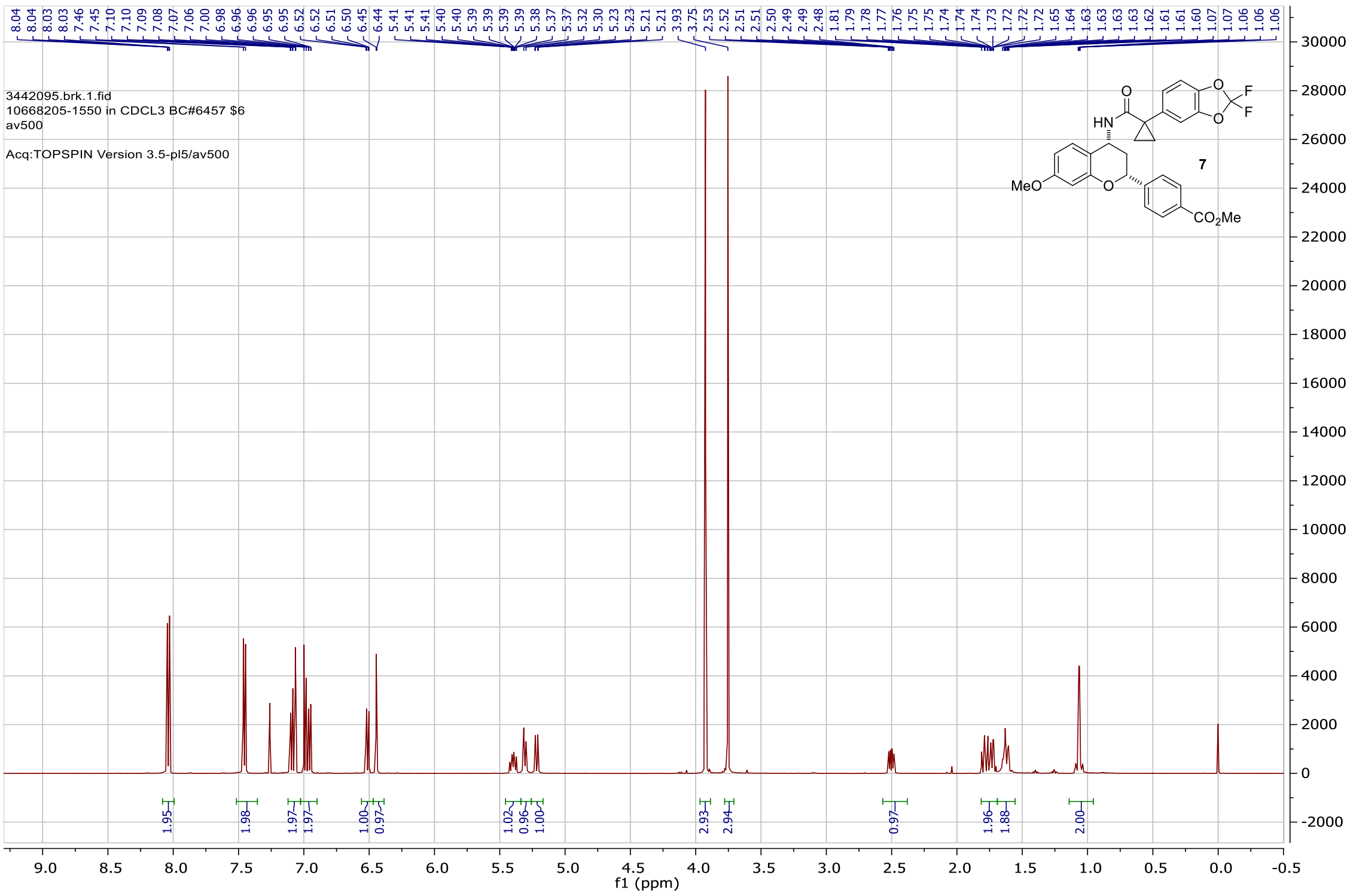




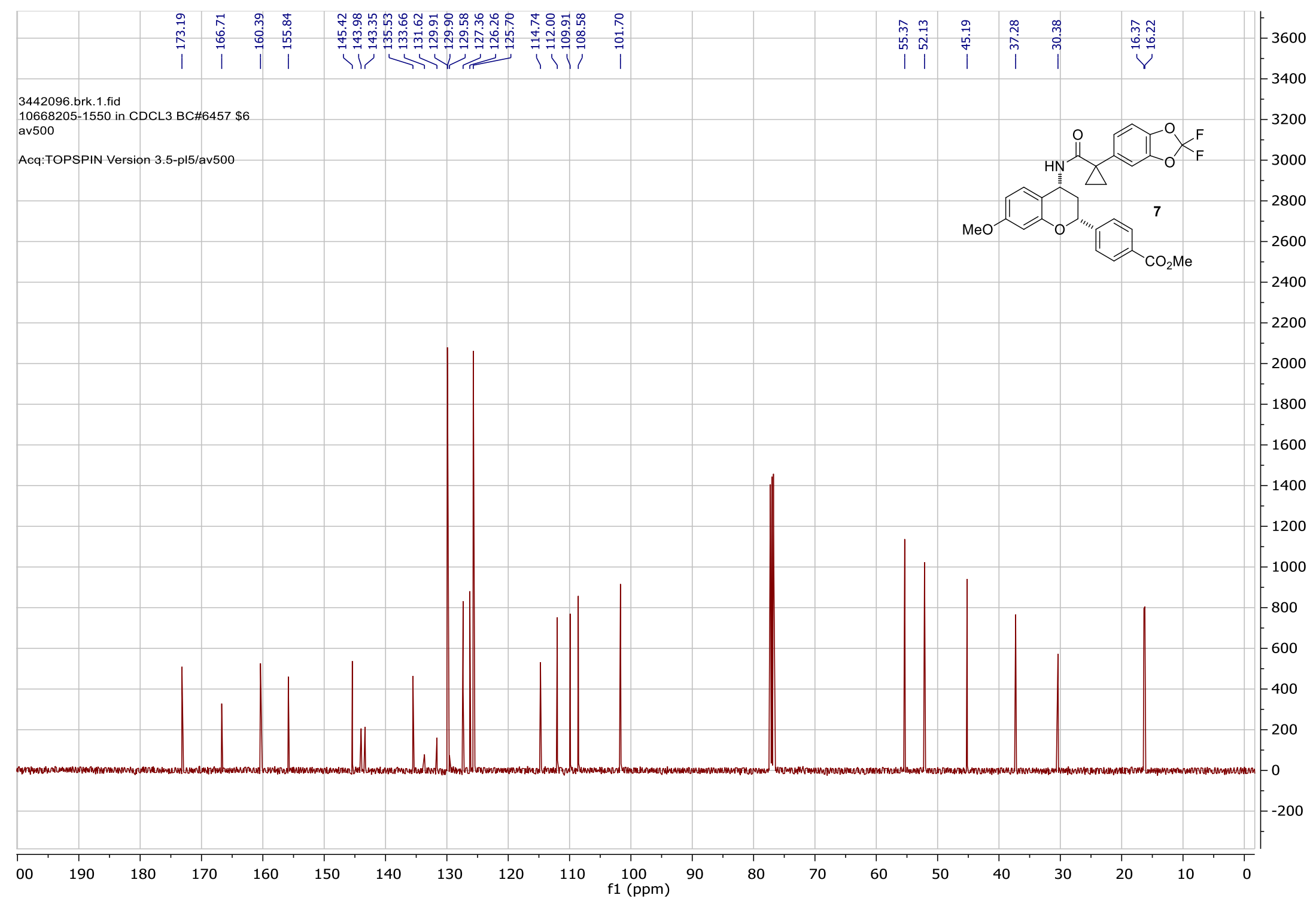




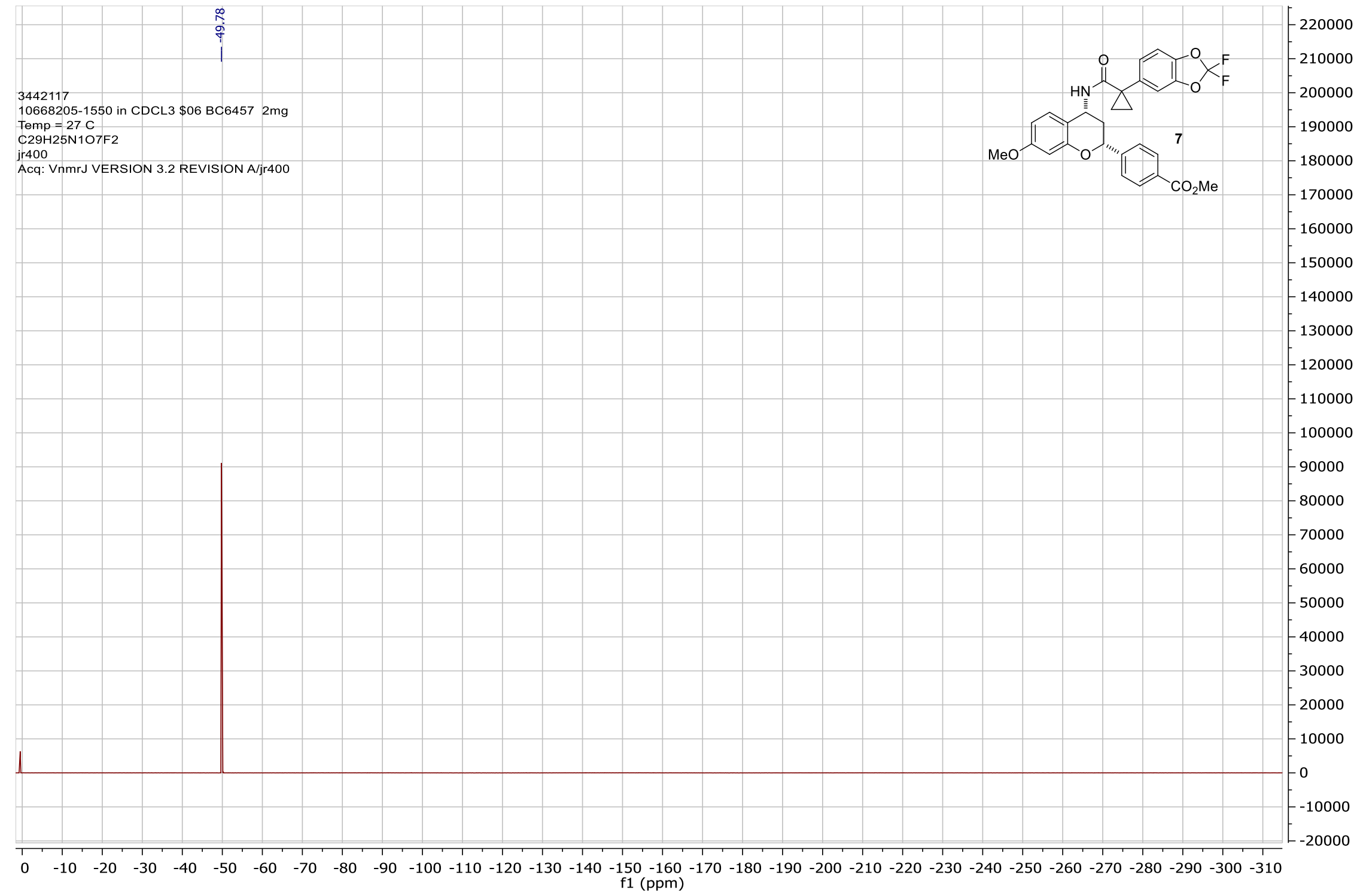




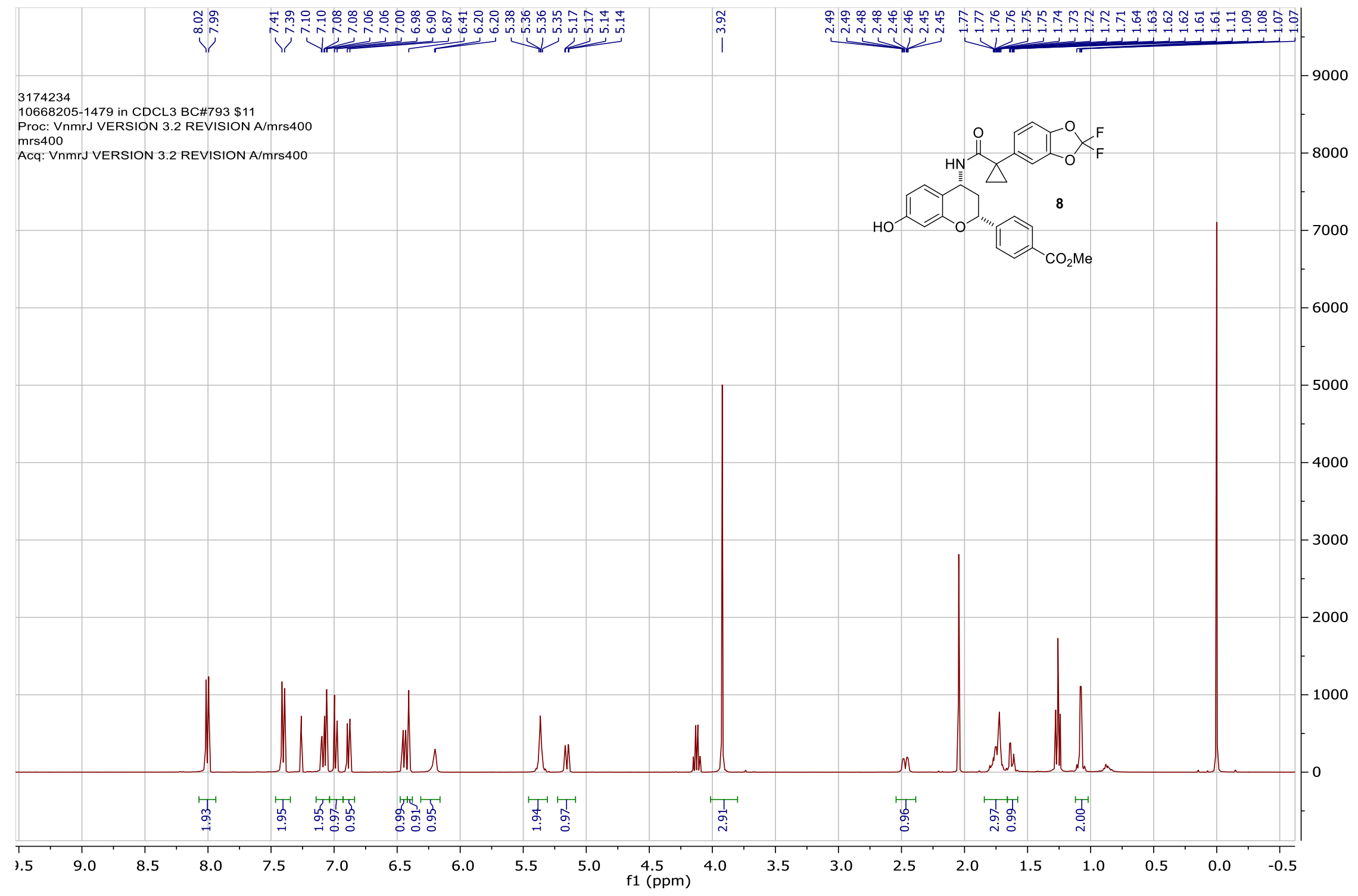




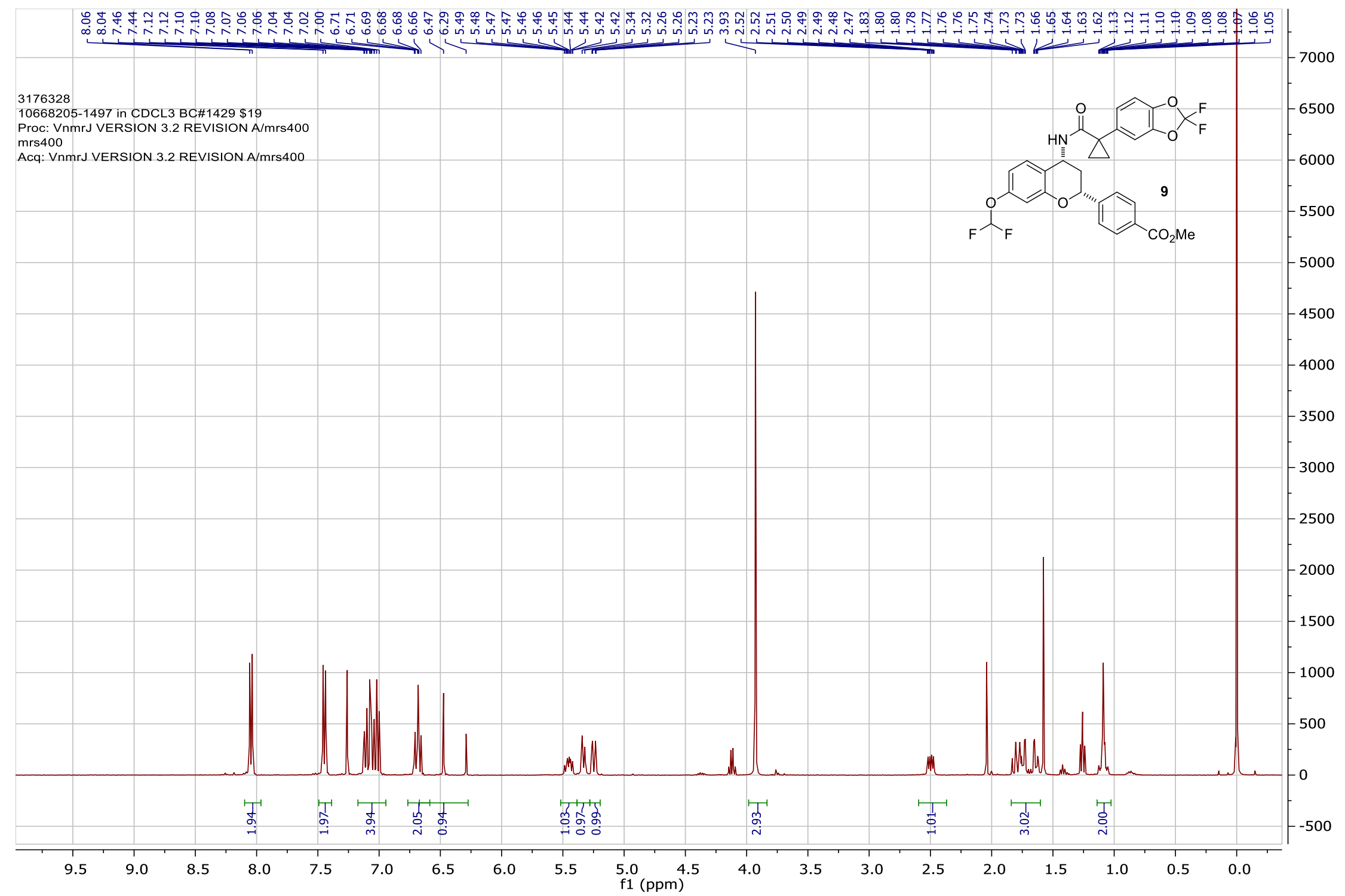




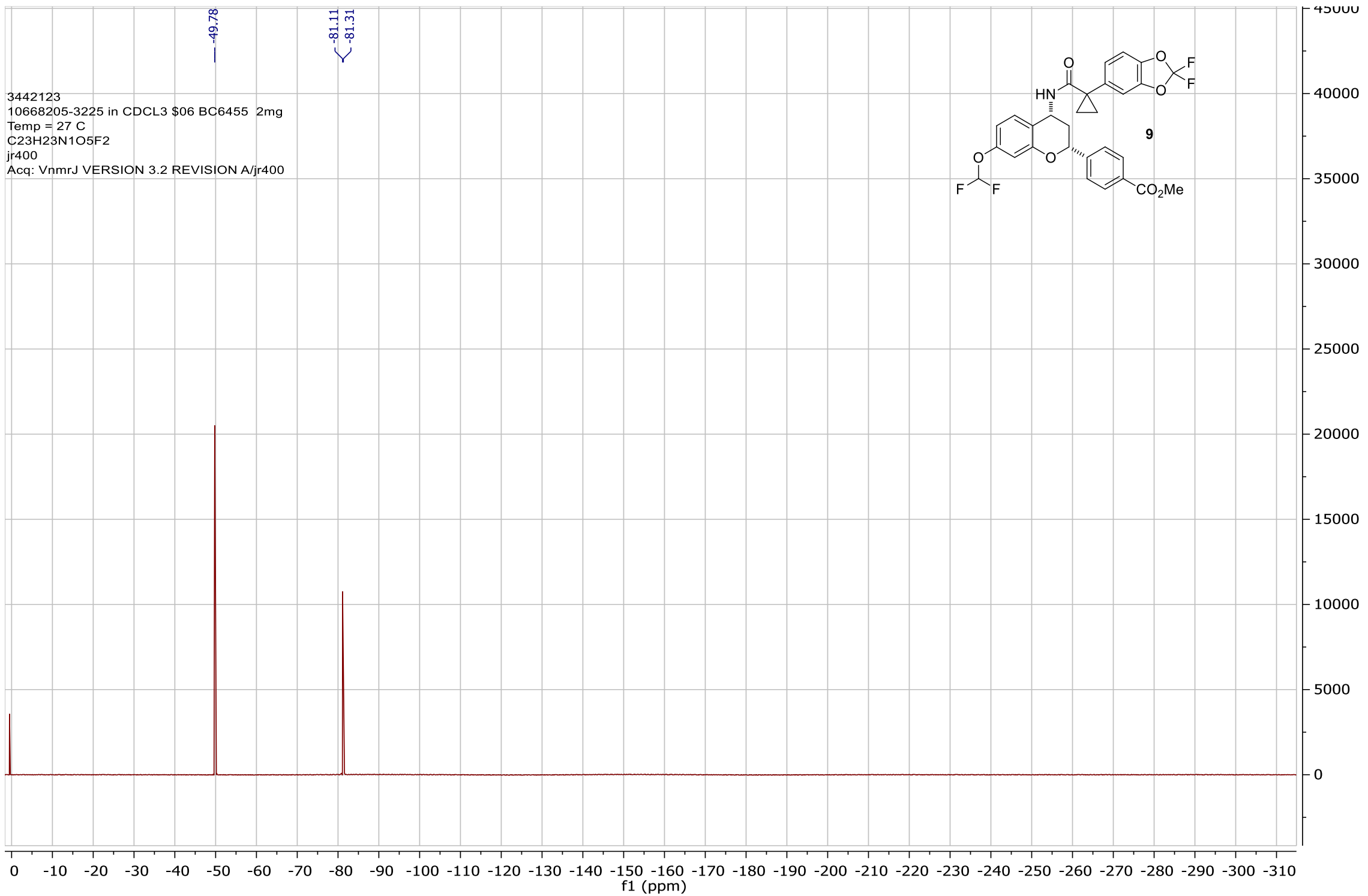




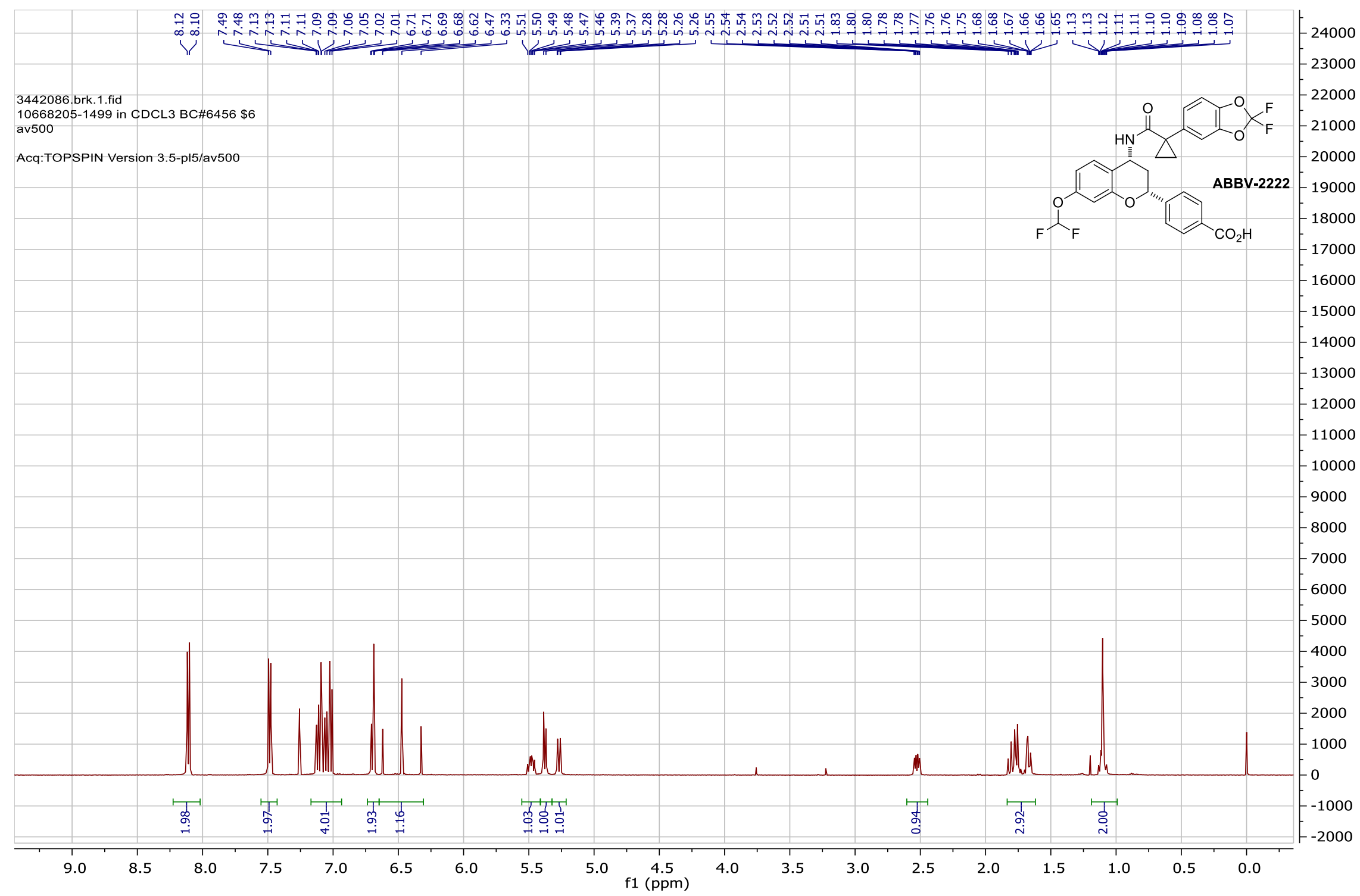




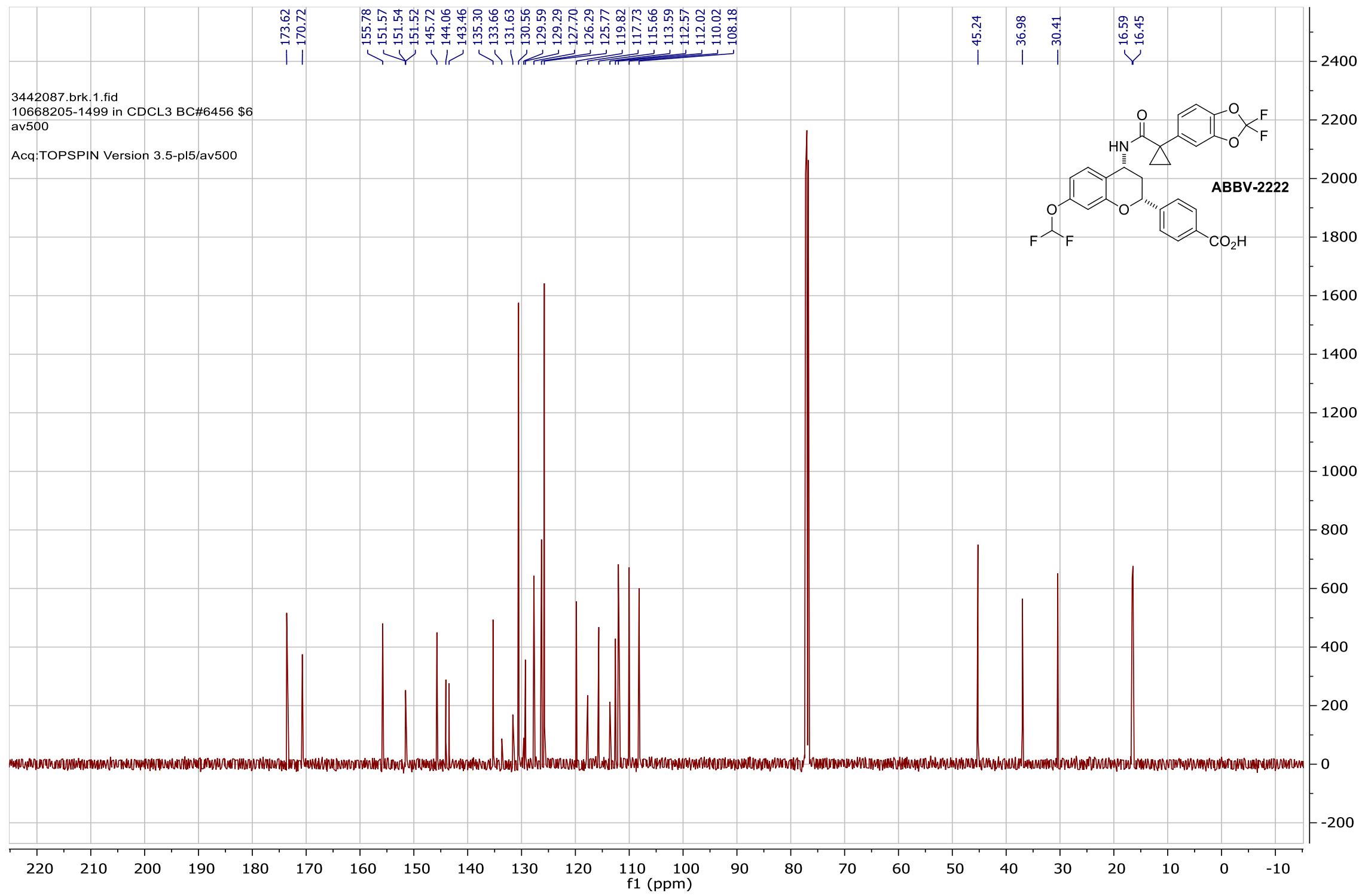

S37 


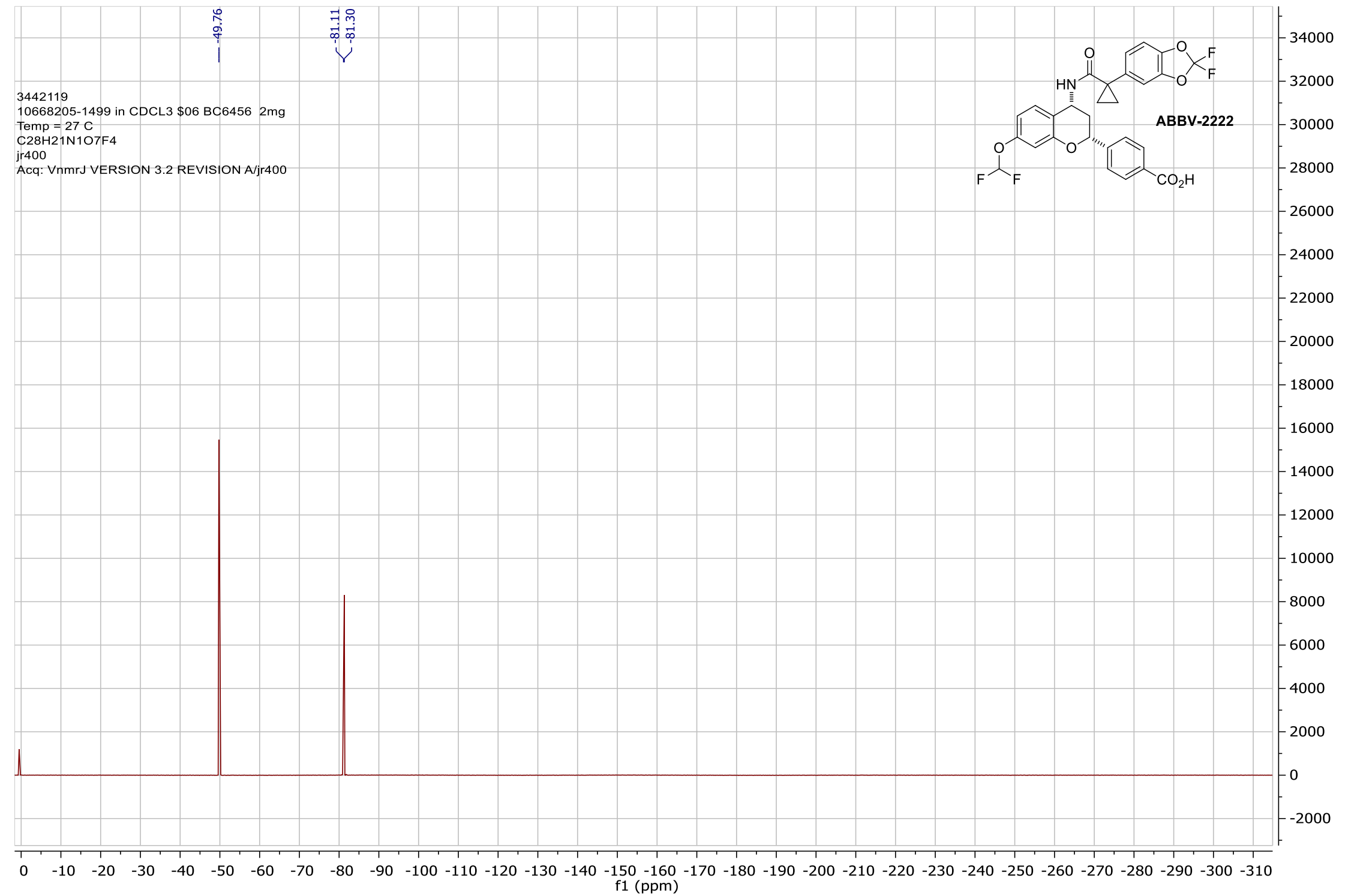




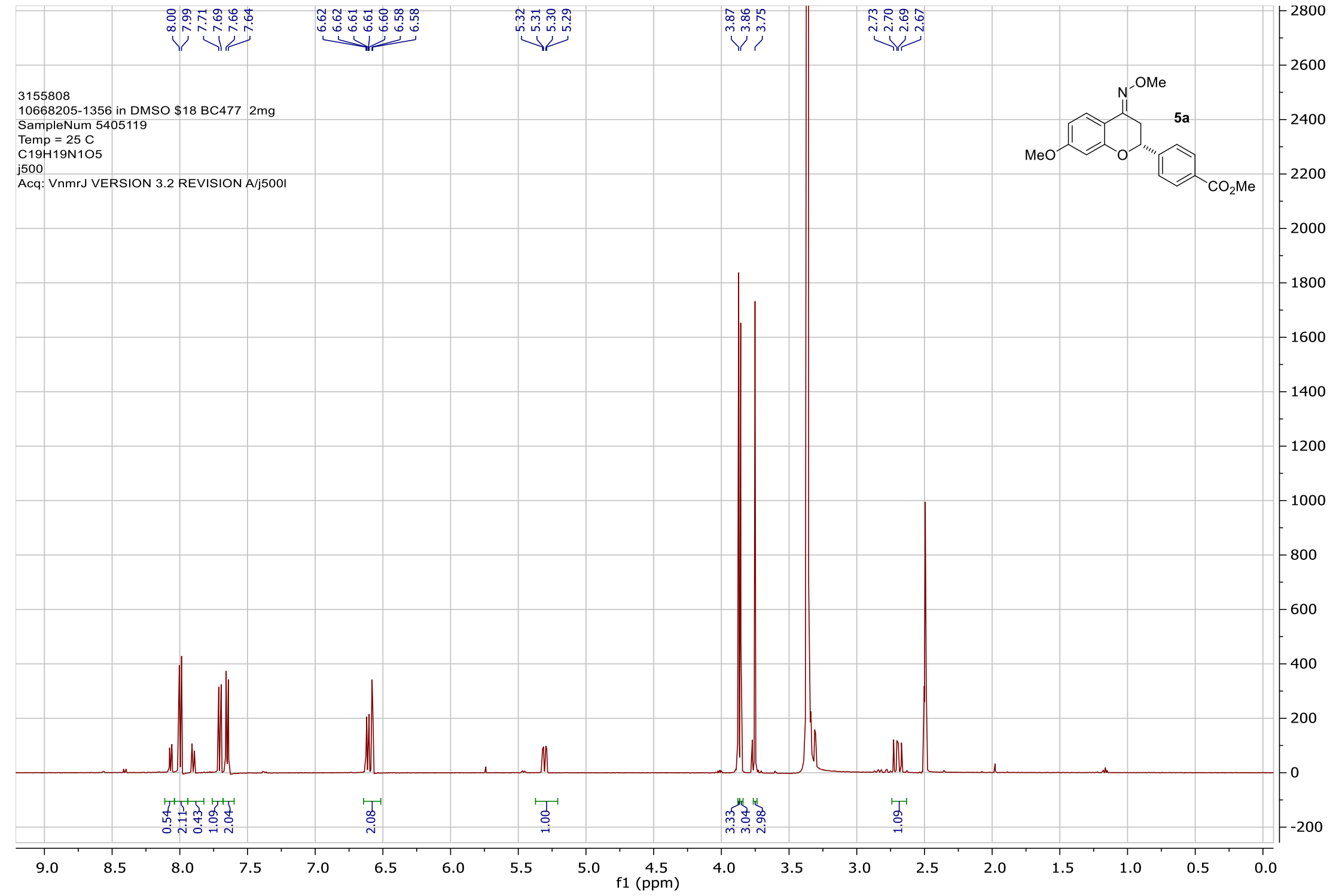

